\begin{tabular}{|c|c|}
\hline Title & Ball loon-borne observations of water vapor and ozone in the tropical upper troposphere and lower stratosphere \\
\hline Author(s) & $\begin{array}{l}\text { Vömel, H.; Oltmans, S. J.; Johnson, B. J.; Hasebe, F.; Shiotani, M.; Fujiwara, M.; Nishi, N.; Agama, M.; Cornejo, J.; } \\
\text { Paredes, F.; Enriquez, H. }\end{array}$ \\
\hline Citation & $\begin{array}{l}\text { Journal of Geophy sical Research A tmospheres, 107(D14), A CL 81-A CL 816 } \\
\text { https://doi.org/10.1029/2001/D000707 }\end{array}$ \\
\hline Issue Date & 2002-07-27 \\
\hline Doc URL & http:/hdl.handle.net/2115/64853 \\
\hline Rights & Copyright 2002 A merican Geophysical Union. \\
\hline Type & article \\
\hline File Information & V-mel_et_al-2002-Journal_of_Geophysical_Research_A tmospheres_(1984 2012).pdf \\
\hline
\end{tabular}

Instructions for use 


\title{
Balloon-borne observations of water vapor and ozone in the tropical upper troposphere and lower stratosphere
}

\author{
H. Vömel, ${ }^{1,2}$ S. J. Oltmans, ${ }^{3}$ B. J. Johnson, ${ }^{3}$ F. Hasebe, ${ }^{4,5}$ M. Shiotani, ${ }^{6,7}$ \\ M. Fujiwara, ${ }^{6,7}$ N. Nishi, ${ }^{8}$ M. Agama, ${ }^{9}$ J. Cornejo, ${ }^{9}$ F. Paredes, ${ }^{9}$ and H. Enriquez ${ }^{9}$ \\ Received 2 April 2001; revised 28 August 2001; accepted 20 November 2001; published 27 July 2002.
}

[1] Balloon-borne observations of frost-point temperature and ozone in the equatorial western, central and eastern Pacific as well as over equatorial eastern Brazil provide a highly accurate data set of water vapor across the tropical tropopause. Data were obtained at San Cristóbal, Galapagos, Ecuador $\left(0.9^{\circ} \mathrm{S}, 89.6^{\circ} \mathrm{W}\right)$, during the late northern winter and the late northern summer in 1998 and 1999 and at Juazeiro do Norte, Brazil $\left(7.2^{\circ} \mathrm{S}\right.$, $39.3^{\circ} \mathrm{W}$ ), in February and November 1997. Earlier data in the western Pacific region in March 1993 were reanalyzed to extend the scope of the observations. The data show three different circumstances in which saturation or supersaturation occurs and imply different mechanisms for dehydration at the tropical tropopause: (1) convective dehydration, (2) slow-ascent dehydration, and (3) large-scale wave-driven dehydration. Furthermore, air that crosses the tropical tropopause in the late northern summer may be dehydrated further during late northern fall, as the average tropical tropopause rises and cools. Not all soundings show dehydration, and there are clear differences in the frequency and depth of saturation in different regions and seasons. The tropopause transition region can be identified in accurate measurements of relative humidity, even under conditions where ozone observations are ambiguous. Deep convection plays an important role in setting up this transition region, which is then subject to large-scale wave activity and wave breaking at the tropopause or midlatitude intrusions. High relative humidities over regions of strong subsidence show that descending motion in the troposphere is limited to levels below the transition region. INDEX TERMS: 3362 Meteorology and Atmospheric Dynamics: Stratosphere/ troposphere interactions; 3374 Meteorology and Atmospheric Dynamics: Tropical meteorology; 0368 Atmospheric Composition and Structure: Troposphere - constituent transport and chemistry; 0341 Atmospheric Composition and Structure: Middle atmosphere - constituent transport and chemistry (3334); KEYWORDS: tropical tropopause, dehydration, stratospheric water vapor, upper troposphere, relative humidity, stratosphere troposphere exchange

\section{Introduction}

[2] Since the discovery of the dryness of the stratosphere [Brewer, 1949], it has been generally accepted that air enters the stratosphere predominantly in the tropics, where the

\footnotetext{
${ }^{1}$ Cooperative Institute for Research in Environmental Sciences, University of Colorado at Boulder, Colorado, USA.

${ }^{2}$ Also at Climate Monitoring and Diagnostics Laboratory, NOAA, Boulder, Colorado, USA.

${ }^{3}$ Climate Monitoring and Diagnostics Laboratory, National Oceanic and Atmospheric Administration, Boulder, Colorado, USA.

${ }^{4}$ Ibaraki University, Ibaraki, Japan.

${ }^{5}$ Now at Graduate School of Environmental Earth Science, Hokkaido University, Sapporo, Japan.

${ }^{6}$ Hokkaido University, Sapporo, Japan.

${ }^{7}$ Now at Radio Science Center for Space and Atmosphere, Kyoto University, Kyoto, Japan.

${ }^{8}$ Radio Science Center for Space and Atmosphere, Kyoto University, Kyoto, Japan.

${ }^{9}$ Instituto Nacionál de Meteorología y Hidrología, Ecuador.

tropopause is cold enough to dry air to the observed low stratospheric water vapor content. The details of how and where air enters the stratosphere and how it is freeze-dried, however, are not well understood. Early investigations based on radiosonde and in situ measurements [Newell and Gould-Stewart, 1981; Kley et al., 1982] indicated that there is a regional and temporal preference for air entering the stratosphere, which has since been referred to as the "stratospheric fountain." Observations of widespread subvisible cirrus clouds near the tropical tropopause in areas outside the traditional fountain region and outside of deep convective regions [Winker and Trepte, 1998] have raised a question as to how much other regions contribute to the dehydration of air in the upper troposphere [Dessler, 1998]. These different points of view show our lack of understanding of the detailed mechanisms by which air enters the stratosphere and the processes that dehydrate the air to the extent observed in the stratosphere.

[3] The increase in stratospheric water vapor since 1980 [Oltmans et al., 2000], which is in contradiction to a cooling trend at the tropical tropopause [Zhou et al., 2001], may contribute as much to stratospheric cooling and tropospheric 


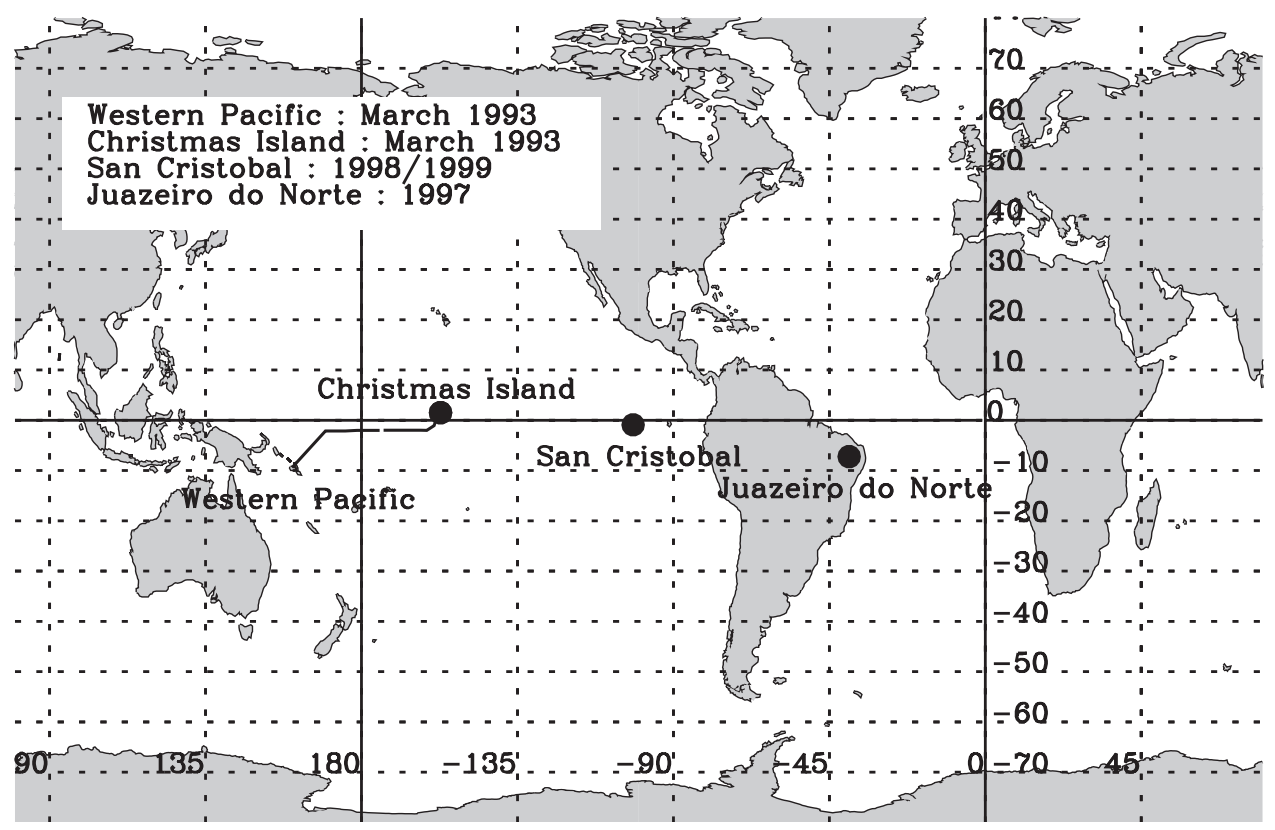

Figure 1. Location of tropical water vapor soundings using the balloon-borne frost-point hygrometer.

warming as a decrease in the concentration of stratospheric ozone [Forster and Shine, 1999; Smith et al., 2001]. Therefore a change in stratospheric water vapor could have important implications for the global climate and a detailed understanding of all mechanisms contributing to the stratospheric water vapor content is needed.

[4] There is ample evidence that the zonal mean properties of the tropical tropopause and lower stratosphere are largely controlled by planetary wave forcing in the midlatitude stratosphere [Holton et al., 1995, and references therein], often called the "extratropical stratospheric pump." Its annual cycle can explain that of the tropical tropopause temperature [Yulaeva et al., 1994]. Combined with the tropical upwelling it also can explain the sequence of minima and maxima in the water vapor profile of the tropical lower stratosphere [Mote et al., 1996], which has since been called the "stratospheric tape recorder." However, important longitudinal differences in the tropical tropopause properties are controlled by the geographical distribution of tropospheric processes, most importantly the strong regional differences in deep convective activity [Highwood and Hoskins, 1998].

[5] Furthermore, there is increasing evidence that the tropopause is not a sharply defined layer but rather a transition layer, with a marked change in vertical stability [Atticks and Robinson, 1983; Selkirk, 1993], a seasonal cycle of temperature best explained by the extratropical stratospheric pump [Reid and Gage, 1996], and a significant increase in ozone [Folkins et al., 1999]. Below this region, vertical transport of air is mostly controlled by deep convection, while above it, vertical transport is controlled by the midlatitude stratospheric pump. It can be expected that this transition region plays an important role in the dehydration of air and the transport of air from the troposphere to the stratosphere.

[6] While some studies assumed a mean, slow rising motion of air near $100 \mathrm{hPa}$, with widespread occurrence of cirrus clouds [Newell and Gould-Stewart, 1981], results from the Stratosphere-Troposphere Exchange Project (STEP [Russel et al., 1993]) and other studies [Danielsen, 1982, 1993; Vömel et al., 1995b; Kley et al., 1996] showed that deep convection in the Western Pacific can transport air from the boundary layer to the tropopause and in overshoots above the tropopause, leading to extremely dry air at the tropopause. Convective systems may also be important for the distribution of subvisible cirrus around the tropical tropopause and their influence on the dehydration of air entering the stratosphere [Wang et al., 1996].

[7] A large difficulty in the clarification of these processes is the sparseness of observations of water vapor around the tropical tropopause. Satellite data lack the vertical resolution to clarify the processes occurring at the tropopause, whereas aircraft and balloon observations lack the global coverage. Here we present balloon borne observations of water vapor, ozone, and temperature in different parts of the equatorial Pacific, and South American region, covering areas with very different convective climatologies. Most data presented here were obtained as part of the Soundings of Ozone and Water in Equatorial Regions (SOWER), which began in 1998 [Hasebe et al., 1999; Vömel et al., 2000] with the goal to study the longitudinal distribution of water vapor and ozone across the equatorial Pacific. The SOWER data shown here were obtained at San Cristóbal, Galápagos, in the eastern Pacific in 1998 and 1999. We also present data obtained at Juazeiro do Norte in northeastern Brazil in 1997 as part of the Observations of the Middle Stratosphere (OMS) and revisit data obtained in 1993 in the Western Pacific as part of the Central Equatorial Pacific Experiment (CEPEX). The geographical distribution of all observations is shown in Figure 1.

\section{Observations}

\subsection{Water Vapor Observations}

[8] All observations are simultaneous balloon-borne observations using frost-point hygrometers, ECC ozone 

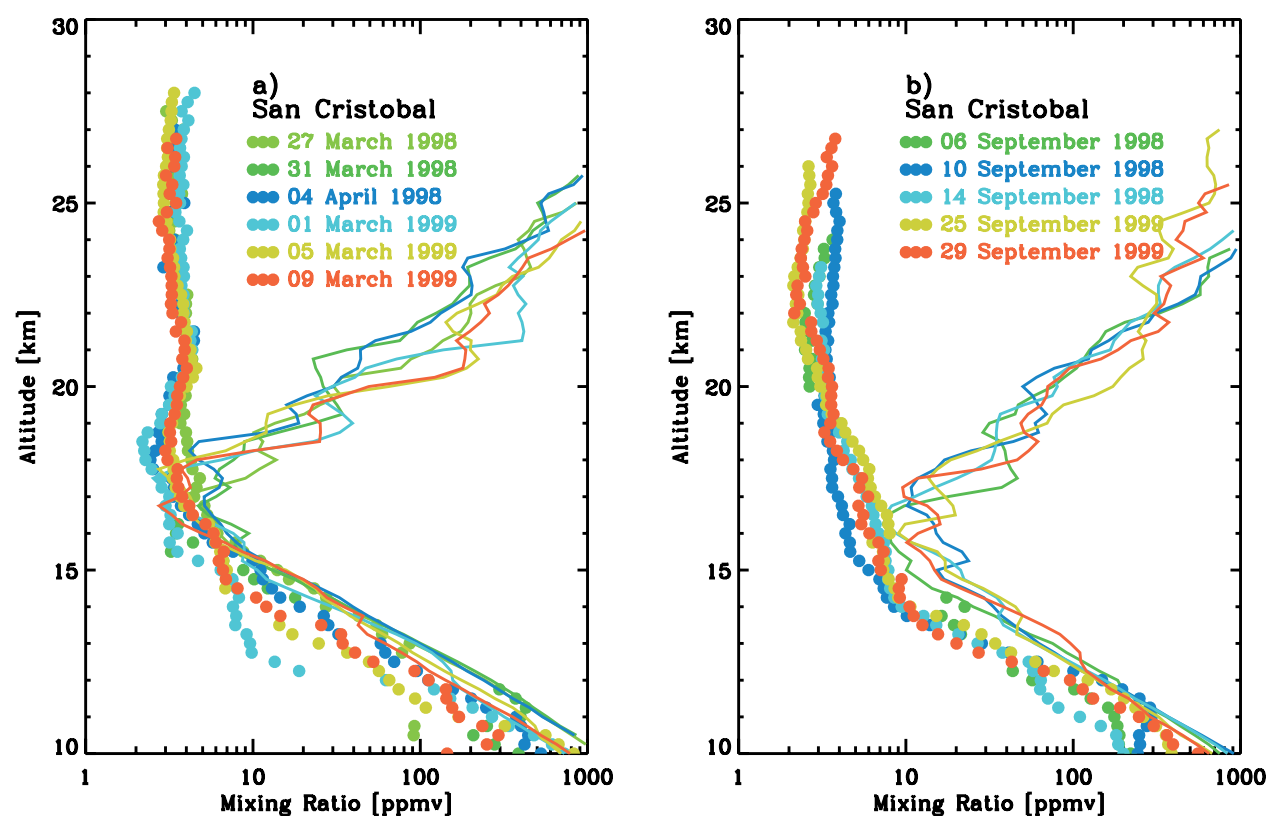

Figure 2. Water vapor (dotted) and saturation (solid) mixing ratio profiles at San Cristóbal, Galapagos, Ecuador in 1998 and 1999: (a) Late winter/spring profiles and (b) September profiles.

sondes and Vaisala radiosondes. Frost-point hygrometers determine the vapor pressure of water by measuring the temperature of a small layer of ice, which has been condensed on a mirror and which is kept in equilibrium with the vapor phase above. The vapor pressure is then calculated from the measured frost-point temperature using a formulation of the Clausius-Clapeyron equation. The accuracy of the water vapor mixing ratio is better than $10 \%$ for typical water vapor mixing ratios [Vömel et al., 1995a]. Ozone is measured using electrochemical concentration cell (ECC) ozone sondes. In these lightweight instruments the reaction of ozone with $\mathrm{I}_{2}^{-}$in a weak aqueous solution of an electrochemical cell offsets the electrochemical equilibrium between the two parts of the cell, creating an electrical current, which is directly proportional to the amount of ozone pumped through the cell [Komhyr et al., 1995]. The accuracy of the ozone mixing ratio is typically $\sim 5 \%$ and slightly lower at low ozone mixing ratios.

[9] The payloads consisting of frost-point hygrometer and ozone sonde are carried to an altitude of around $30 \mathrm{~km}$ by small meteorological balloons. Pressure, temperature, and lower tropospheric relative humidity are measured by radiosondes, which also transmit the data of the frost-point hygrometer and the ECC sonde.

\subsubsection{San Cristóbal, Galapagos, Ecuador:}

March/April and September 1998/1999

[10] Four campaigns took place in 1998 and 1999 at San Cristóbal, Galapagos, and Ecuador $\left(0.9^{\circ} \mathrm{S}, 89.6^{\circ} \mathrm{W}\right)$ as part of SOWER, with one in March and one in September of each year. The times of the campaigns were chosen near times of coldest and warmest tropical tropopause temperatures. In each deployment, three water vapor/ozone sondes, three additional ozone sondes, and at least daily radiosondes were launched. Since September 1998, ozone sondes have been launched biweekly, and weekly since
March 1999 as part of the Southern Hemisphere Additional Ozone Sondes (SHADOZ) project [Thompson et al., 2002]. The March 1998 observations were strongly influenced by the record El Niño 1997/1998, while the following campaigns were influenced by the La Niña, which began in June 1998.

[11] The March data (Figure 2a) show water vapor minima of 2.3 to 3.2 parts per million by volume (ppmv) between 18.5 and $19.2 \mathrm{~km}$. One profile on 27 March 1998 shows a water vapor minimum of 3.7 ppmv. The saturation mixing ratio shows that the uppermost troposphere is close to saturation or even supersaturated in most profiles.

[12] The September data (Figure 2b) show a markedly different structure with typical non-saturated water vapor minima of 2.3 to 2.8 ppmv near $22.5 \mathrm{~km}$. The profile on 10 September 1998 shows a nearly constant water vapor mixing ratio around $3.6 \mathrm{ppmv}$ between 18 and $22 \mathrm{~km}$. The soundings on 6 and 10 September 1998 show almost identical structures and values as a sounding reported by Kley et al. [1979] using a balloon borne Ly a hygrometer on 27 September 1978 near Juazeiro do Norte, Brazil.

\subsubsection{Juazeiro do Norte, Brazil, February} and November 1997

[13] OMS deployments took place in February and November 1997 at Juazeiro do Norte, Brazil $\left(7.2^{\circ} \mathrm{S}\right.$, $\left.39.3^{\circ} \mathrm{W}\right)$. Water vapor was measured as part of the large OMS payload and simultaneously on small, free-flying balloons. Owing to water vapor contamination onboard the OMS payload, only data from the free-flying instruments are used here. The water vapor profile on 14 February 1997 (Figure 3a) shows strong similarities to the profiles obtained in March 1998 and March 1999 over San Cristóbal. The water vapor minimum is $2.7 \mathrm{ppmv}$ at $18.6 \mathrm{~km}$, which is slightly above the tropopause region. The profile on 11 November 1997 (Figure 3b) is significantly different, with two minima at $16.6 \mathrm{~km}$ and at 20.3 

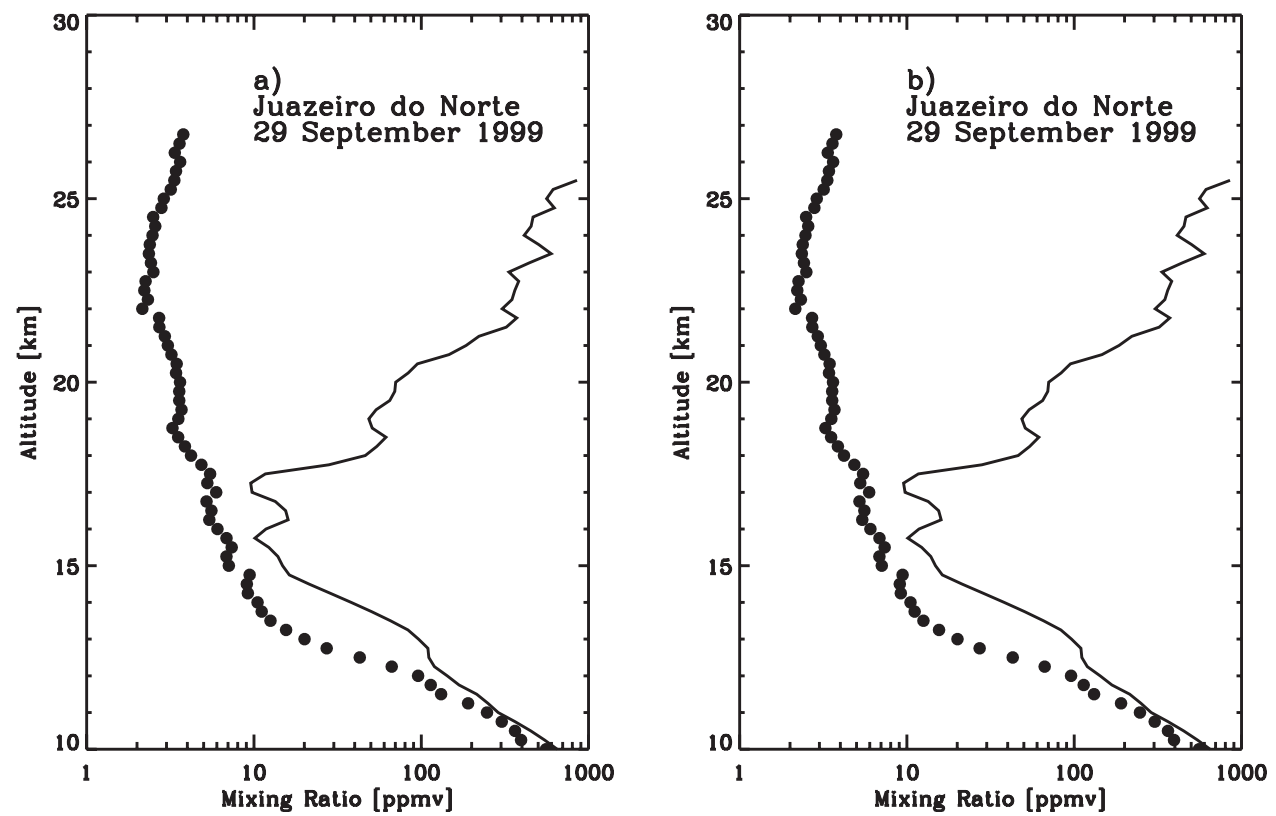

Figure 3. Water vapor (dotted) and saturation (solid) mixing ratio profiles at Juazeiro do Norte, Brazil: (a) 14 February 1997 and (b) 11 November 1997.

$\mathrm{km}$. Both profiles show that the upper troposphere is not saturated.

\subsubsection{Western Pacific, March 1993}

[14] Thirteen water vapor/ozone profiles and 14 additional ozone profiles were obtained in March 1993 onboard the research vessel $\mathrm{R} / \mathrm{V}$ Vickers (mostly along $2^{\circ} \mathrm{S}$, between $160^{\circ} \mathrm{E}$ and $\left.157^{\circ} \mathrm{W}\right)$ and on Christmas Island $\left(1.5^{\circ} \mathrm{N}\right.$, $\left.157^{\circ} \mathrm{W}\right)$. Some of these data have been published previously [Vömel et al., 1995b; Kley et al., 1997, 1996]. The cruise traversed a region of deep convective activity between $160^{\circ} \mathrm{E}$ and approximately the dateline, followed by a region with suppressed convection, roughly between the dateline and Christmas Island.

[15] The data show extremely low water vapor concentrations (typically $1.5 \mathrm{ppmv}$ ) in the tropopause region in the western Pacific (Figure 4a) and central Pacific (Figure 4b). The lowest observed water vapor mixing ratio was 0.7 ppmv. The profiles at Christmas Island are very similar to those at San Cristóbal in March and Juazeiro do Norte in February, with values near 2.8 ppmv in the tropopause region. This is below the mean value of $3.5 \mathrm{ppmv}$ in the tropical lower stratosphere. The profiles in the western and central Pacific are similar to the profiles at San Cristóbal and Juazeiro do Norte only above $17.5 \mathrm{~km}$.

\subsection{Temperature Observation Near the Tropical Tropopause}

[16] Throughout this paper the tropopause is defined by the level where the lapse rate changes to less than $2 \mathrm{~K} / \mathrm{km}$
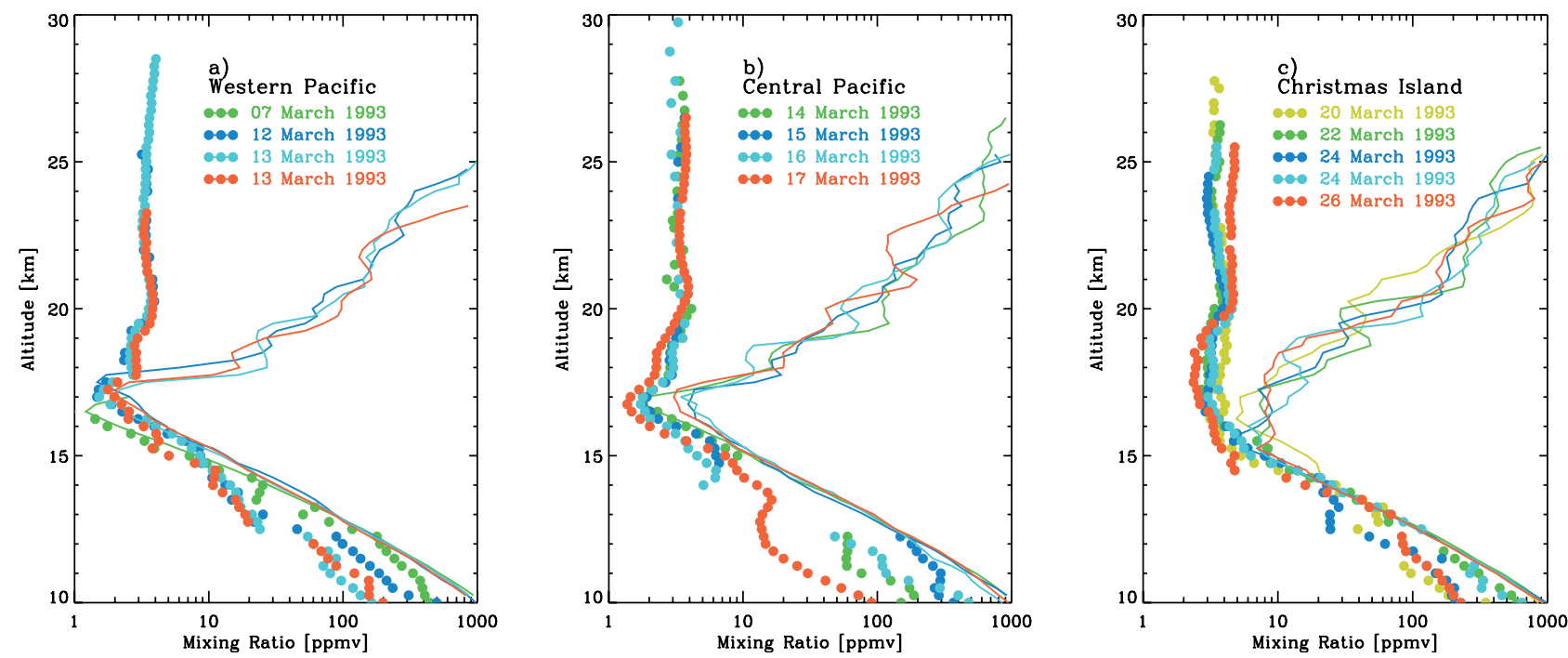

Figure 4. Water vapor (dotted) and saturation (solid) mixing ratio profiles during CEPEX 1993: (a) Western Pacific, (b) Central Pacific, and (c) Christmas Island. 


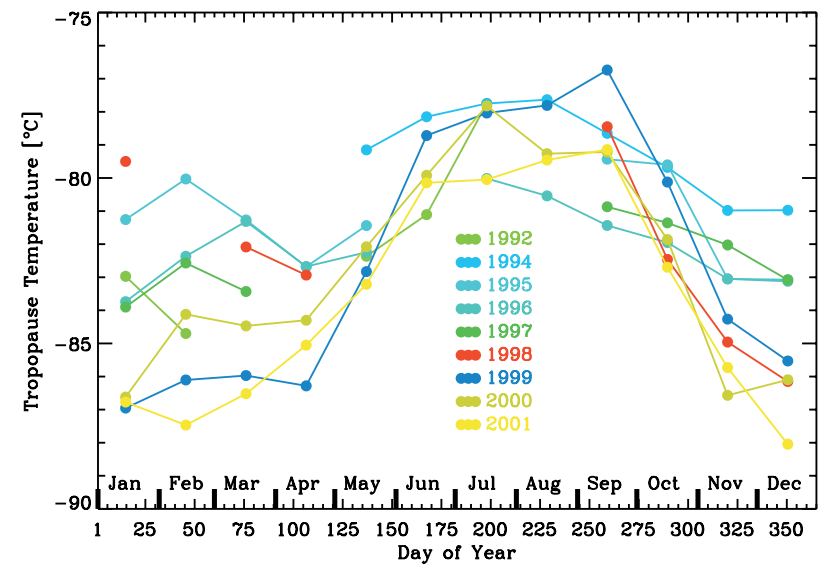

Figure 5. Monthly mean tropopause temperature at San Cristóbal between 1992 and 2001 from regular soundings.

for at least $2 \mathrm{~km}$ [World Meteorological Organization $(W M O), 1957]$. In some cases, we will explicitly refer to the level of minimum temperature or the level of minimum saturation mixing ratio, the latter having most physical significance in terms of water vapor entry level.

[17] At San Cristóbal, regular ozone sonde and radiosonde ascents provide highly accurate temperature profiles. The seasonal cycle of the tropopause temperature at San Cristóbal is shown in Figure 5, using data obtained in several periods between 1992 and 2001. The monthly mean tropopause temperature typically varies between $-80^{\circ} \mathrm{C}$ and $-87^{\circ} \mathrm{C}$ during the cold period (December to April) and between $-77^{\circ} \mathrm{C}$ to $-82^{\circ} \mathrm{C}$ during the warm period (June to September). The transition between the warm and cold periods occurs between September and November. This cycle is more pronounced in the mean saturation mixing ratio, which can vary between 2 and 5 ppmv during the cold period, and between 5 and 8 ppmv during the warm period. Individual soundings show tropopause temperatures as low as $-91^{\circ} \mathrm{C}$ and saturation mixing ratios as low as $1 \mathrm{ppmv}$. The tropopause in March/April 1999 is $3{ }^{\circ} \mathrm{C}$ colder than in March/April 1998, while in September 1999 it is $2^{\circ} \mathrm{C}$ warmer than in September 1998. The altitude of the temperature minimum at San Cristóbal shows a strong seasonal cycle, lying near $17.3 \mathrm{~km}$ in December through April and around $16.0 \mathrm{~km}$ in June to September. The potential temperature of the tropopause does not show a significant seasonal cycle, which is on average between 370 and $374 \mathrm{~K}$.

[18] In four soundings at Juazeiro do Norte (two of which are shown in Figure 3) tropopause temperatures are significantly warmer than the average at San Cristóbal for the respective months (Figure 6). Regular soundings at Natal, Brazil, $\sim 450 \mathrm{~km}$ to the northeast, show that the average tropopause temperature in this region is several degrees warmer than at San Cristóbal, so that the observations at Juazeiro do Norte are near the longer term mean of this region. The soundings in the western Pacific in March 1993 are significantly colder, while the Christmas Island data are warmer than the San Cristóbal data. The event at Christmas Island associated with these warmer temperatures is discussed below.
[19] The tropopause potential temperature at Juazeiro do Norte is similar to that at San Cristóbal, but in the western and central Pacific it is significantly lower, with an average of $365 \mathrm{~K}$ and a range of 352 to $386 \mathrm{~K}$. Again, there is a significant difference between the observations in the western Pacific and at Christmas Island. The first two soundings at Christmas Island show a tropopause potential temperature of around $370 \mathrm{~K}$; the following seven soundings show much lower values around $357 \mathrm{~K}$, producing an over all lower average.

[20] This limited temperature data set agrees well with previous studies of the temperature distribution along the tropical tropopause [Newell and Gould-Stewart, 1981; Atticks and Robinson, 1983; Nishida et al., 2000]. The tropopause is generally coldest over the western Pacific, and warmest over South America and the Western Atlantic. The majority of the ozone and water vapor observations represent the average conditions at these sites.

\subsection{Ozone Observations Near the Tropical Tropopause}

[21] Figure 7 shows the monthly mean ozone mixing ratio at the tropopause at San Cristóbal between 1998 and 2001, at Juazeiro do Norte in 1997 and in the Western Pacific in March 1993. At San Cristóbal the ozone concentration at the tropopause is on average $85 \mathrm{ppbv}$, with no apparent seasonal cycle. During the campaign in September 1998, which also marks the start of regular soundings at San Cristóbal, unusually high tropopause ozone values were observed. Successive soundings, separated by 2 days, showed values of 193 and 241 ppbv; after two more such elevated measurements, they returned to more normal values below 100 ppbv. No other event of this magnitude has been observed. The ozone concentrations at Juazeiro do

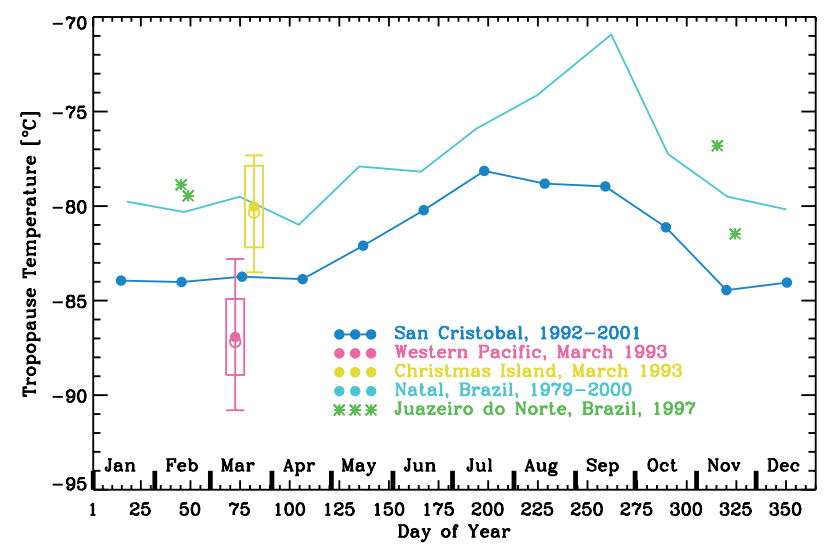

Figure 6. Tropopause temperature at San Cristóbal, Juazeiro do Norte, and the Western Pacific. For San Cristóbal the monthly mean values of all regular soundings between 1992 and 2000 are shown. At Juazeiro do Norte, only four soundings are available and these data are shown as individual points. For the Western Pacific all data from the CEPEX cruise in March 1993 as well as the data from Christmas Island are shown in a distribution bar. The solid dot marks the mean of all soundings; the circle marks the median of all soundings; the box marks the standard deviation; the extremes mark the maximum and minimum observations. 


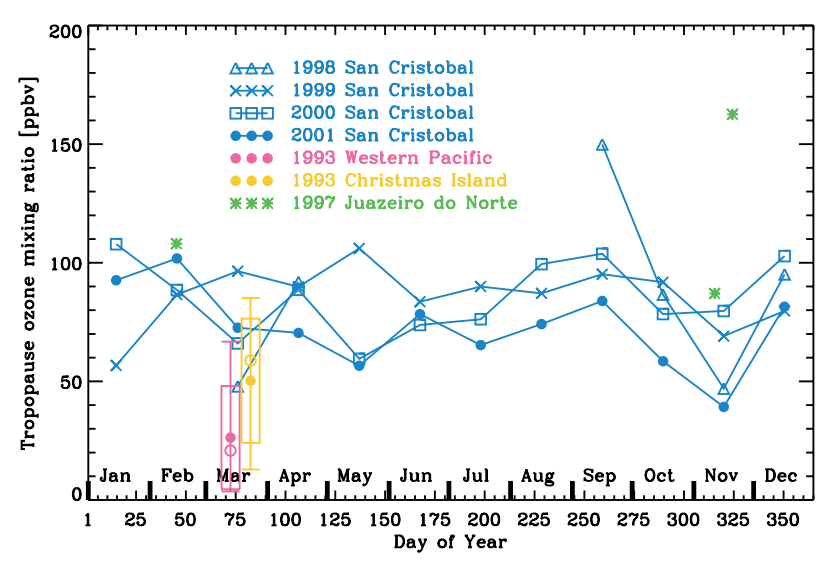

Figure 7. Ozone mixing ratio at the tropopause. The monthly mean data at San Cristóbal are shown for each year. At Juazeiro do Norte the individual data points are shown. For the Western Pacific the data are shown in a distribution bar (see Figure 6 for explanation).

Norte are higher than the San Cristóbal mean values throughout the entire troposphere and at the tropopause. In the Western Pacific, extremely low ozone values may characterize the entire upper troposphere [Kley et al., 1996]. The mean tropopause ozone mixing ratio was around 35 ppbv, which includes the significantly higher ozone values at the tropopause at Christmas Island.

\section{Discussion}

\subsection{Supersaturation and the Presence of Ice Particles}

[22] Studying the dehydration at the tropical tropopause in detail would require simultaneous observations of cloud particles, which could unequivocally identify the removal of water substance from an air mass through the sedimentation of ice particles [e.g., Vömel et al., 1997; Miloshevich et al., 2001]. Our observations are limited to water vapor and ozone, which provide information only about the level of saturation or supersaturation, but not whether ice particles are present. However, supersaturation observed in most spring profiles, combined with large temperature variations during the observation period, strongly suggests the presence of ice particles. Figure 8 shows the water vapor mixing ratio on 9 March 1999 and all ice-saturation mixing ratios observed between the day before and after this sounding. Relative humidity with respect to ice (RHI) peaks at $16.8 \mathrm{~km}$ with a value of $150 \%$, which is near the threshold, where cirrus cloud nucleation is expected to occur [Tabazadeh et al., 1997]. Assuming the same water vapor amounts, the temperature variations shown in Figure 8 would correspond to values of RHI between 100 and $180 \%$ in the region between 15.8 and $17.8 \mathrm{~km}$, again strongly suggesting the formation of ice particles at some time within this 3-day period. Once ice particles have formed in this altitude range, they are unlikely to evaporate during this period, since temperatures stayed cold enough. In the case shown here, ice particles could settle up to $2 \mathrm{~km}$, before encountering subsaturated air and evaporating.

[23] Temperature variations of this kind were typical for all observations where saturation or supersaturation was observed. Therefore we assume that ice particles are present, if an air mass is at least saturated with respect to ice. We will use the term dehydration in the sense of active removal of water substance through the sedimentation of ice particles, and we will use saturation as a proxy for dehydration throughout most of the discussion.

\subsection{Regional Variation of Dehydration at the Equatorial Tropopause}

\subsubsection{Deep-convective dehydration}

[24] The first profile in the western Pacific in March 1993 was obtained very close to a deep convective event (Figure 9a) and showed saturation throughout most of the profile with extremely low ozone mixing ratios $(<5 \mathrm{ppbv})$ in the upper troposphere and an extremely low water vapor mixing ratio at the temperature minimum. Other profiles near but outside the region of deep convection showed similar results. In these profiles, air was dehydrated in the rapid ascent from the surface to the upper troposphere and the extremely cold temperature and dry water vapor minima were clearly a result of the deep convection [Vömel et al., 1995b].

[25] The details of deep convection are not important in distinguishing convective dehydration from the other types discussed below. The only important consideration is that air is transported rapidly from near the surface to the upper troposphere, while drying out at the same time. Further

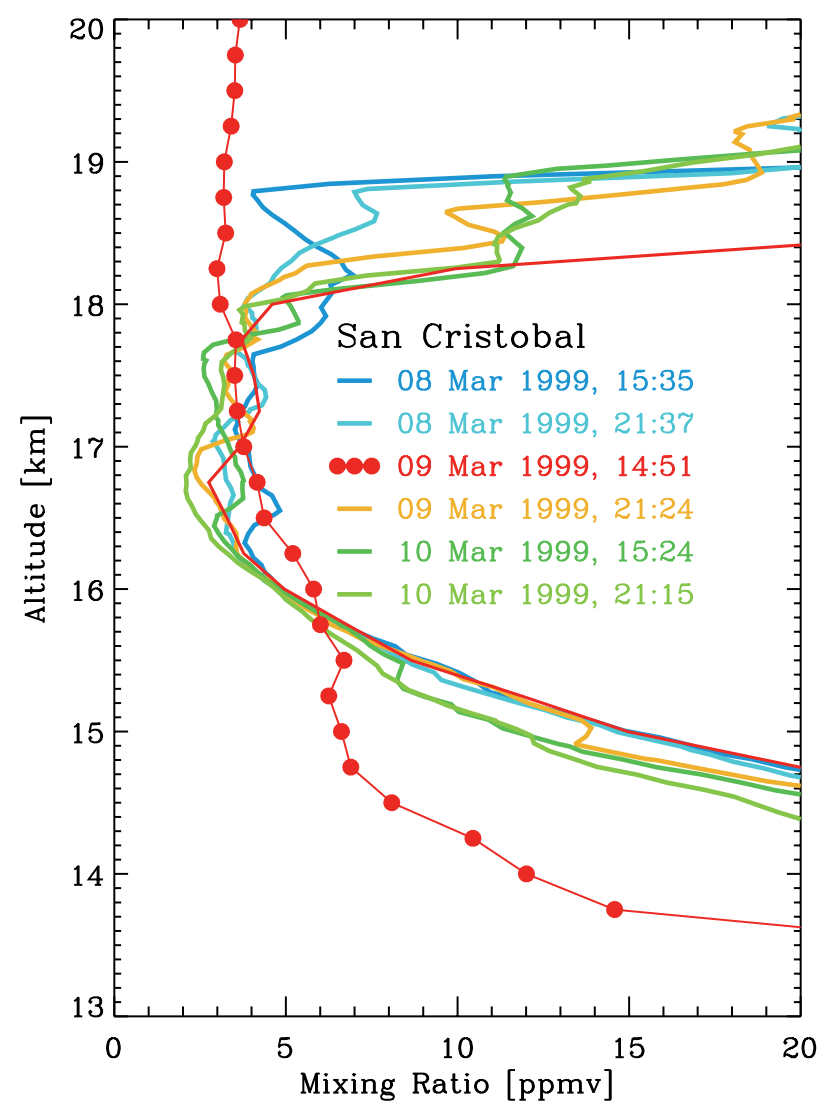

Figure 8. Water vapor (dotted) and saturation (solid) mixing ratio profiles for the time between 8 and 10 March 1999. Only one water vapor profile was measured on 9 March 1999, while the saturation mixing ratio profiles are calculated from twice daily radiosoundings. 

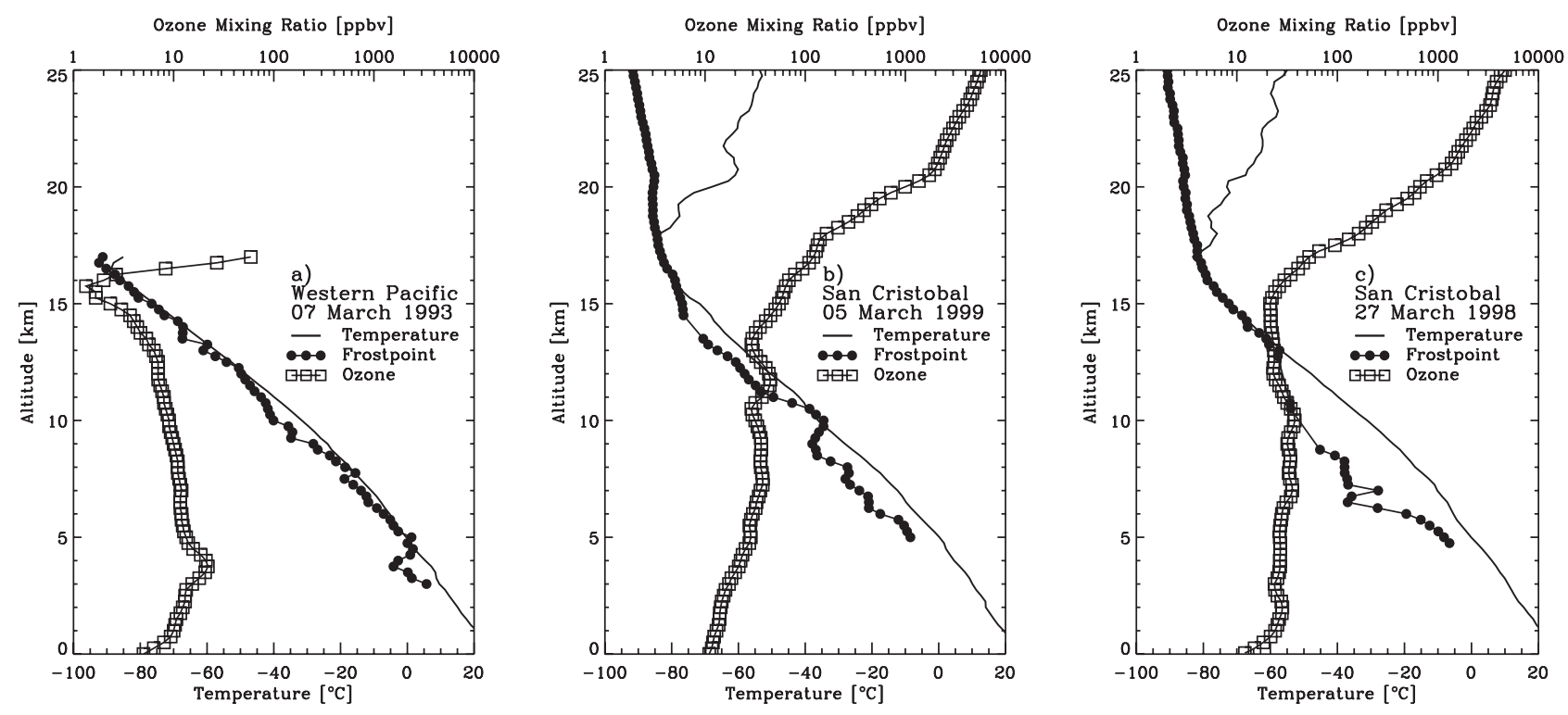

Figure 9. Ambient temperature, frost-point temperature and ozone mixing ratio for selected profiles during the spring period: (a) Western Pacific, deep convective, March 1993, (b) Eastern Pacific, nonconvective, March 1999, and (c) Eastern Pacific, March 1998.

dehydration of the air in cirrus anvils as suggested in some mechanisms [e.g., Danielsen, 1993] is considered here equivalent to generic deep convective influence.

[26] In all soundings in the western Pacific the water vapor concentrations at and below the tropical tropopause were lower than any other observations at Christmas Island, San Cristóbal, and Juazeiro do Norte. Note that this longitudinal difference extends only up to the tropopause, but not above, with a very sharp gradient at the tropopause.

[27] Several studies have indicated that deep convection may not transport large amounts of air into the lower stratosphere. Gage et al. [1991] and Sherwood [2000] showed that in areas of deep convection there is a mean downward motion in the lowermost stratosphere. This descent above deep convection together with the ascent inside of deep convection could explain the extremely steep gradients in water vapor and ozone over a large area at the tropopause. Air, which has been transported to the tropopause in deep convective events, may be transported horizontally and consequently enter the stratosphere through slow rising motion away from the area of deep convection. Thus convective dehydration at the temperature minimum and entry into the stratosphere are not necessarily collocated processes.

[28] Nishida et al. [2000] generated maps of the global tropopause temperature and found that in the western Pacific the coldest regions do not coincide with the regions of lowest outgoing longwave radiation (OLR), which gives the cloud top temperature at the top of deep convective systems. This implies that even if air reached the tropopause in deep convective towers, further processing may be occurring before air can be called stratospheric.

\subsubsection{Slow-ascent dehydration}

[29] The observations in the eastern Pacific in March 1999 show a very different process. The middle troposphere is dry, while the upper troposphere between $15.5 \mathrm{~km}$ and the temperature minimum at $17.7 \mathrm{~km}$ is saturated (Figure 9b). The much higher upper tropospheric ozone concentrations indicate that this air has not recently ascended from the surface, but rather has undergone some processing through mixing with stratospheric air and possibly in situ production of ozone [Folkins et al., 1999]. This saturation occurs in the absence of a deep convective influence and implies active dehydration outside of deep convective regions. The profile shown in Figure 9b was taken 4 days before the observation shown in Figure 8 and discussed in section 3.1 and is similar in the level of supersaturation and probability for the presence of ice particles.

[30] The observations in March 1998 were obtained during the very strong El Niño of 1997/1998. The entire troposphere is moister and the upper tropospheric air is saturated and partly supersaturated between $13 \mathrm{~km}$ and the temperature minimum at $17 \mathrm{~km}$ (Figure 9c), again implying dehydration. Deep convection was closer to San Cristóbal, but did not reach the same altitude as in the western Pacific. In particular, it did not reach the altitude of the temperature minimum. The saturation in the tropopause region of the eastern Pacific is consistent with slow ascent driven by the extratropical stratospheric pump, whereas in the western Pacific the deep convection may be the dominating mechanism.

[31] In March 1998 the saturation layer was typically above deep convection and cirrus clouds could be seen above anvil clouds. Hartman et al. [2001] pointed out that the radiative balance within these cirrus clouds is dramatically different compared to high cirrus without underlying anvils, which may enhance dehydration of the air as soon as initial cirrus clouds have formed.

\subsubsection{Large-scale wave-driven dehydration}

[32] As mentioned earlier, tropopause ozone concentrations at San Cristóbal were unusually high during the campaign in September 1998. This event is connected to an eastward propagating Kelvin wave [Fujiwara et al., 2001]. The profile on 10 September 1998 shows higher ozone concentrations (Figure 10a) and lower relative humidity (Figure 10b) extending to at least one km below the tropopause. This profile shows the downward phase of the passing wave event. The sounding 4 days later shows lower 

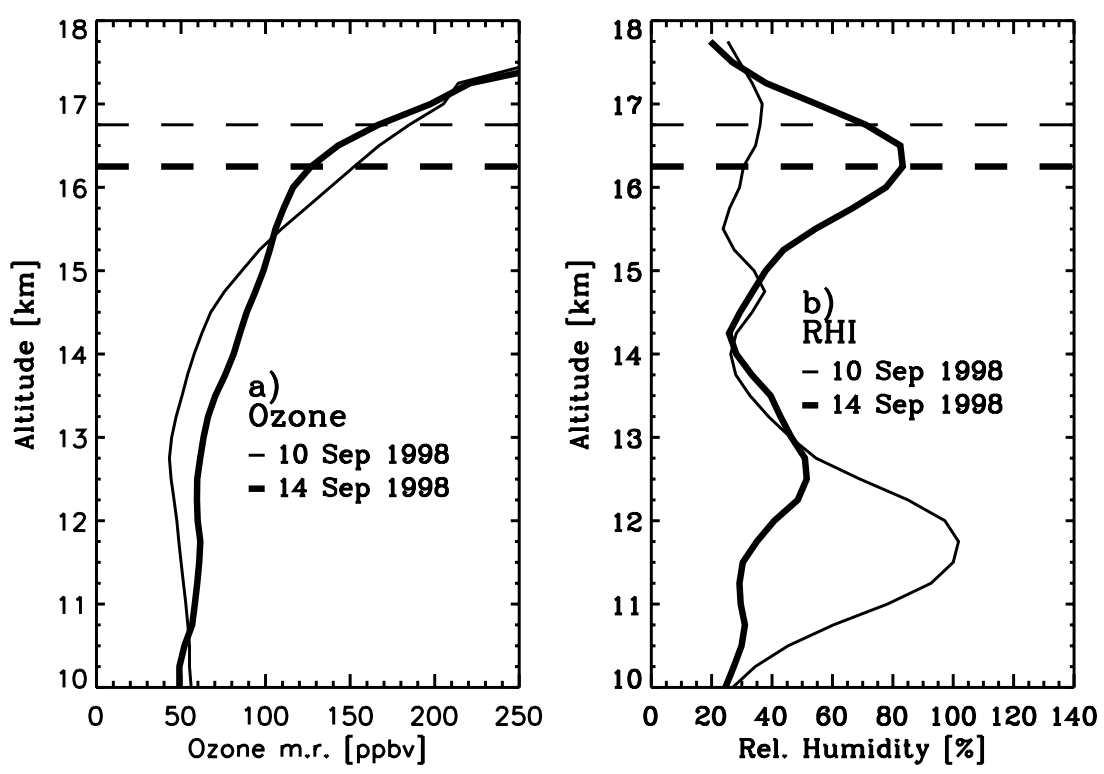

Figure 10. Passing Kelvin wave between 10 and 14 September 1998 in the profiles of (a) ozone and (b) relative humidity with respect to ice.

ozone and much higher relative humidity over the same altitude region, representing the upward phase of this wave event. The tropopause in the latter observation is close to saturation, allowing for the possibility of dehydration in the upward phase. This is the only event of this type that has been observed at San Cristóbal. The conditions at the tropical tropopause may allow breaking of Kelvin waves, but wave breaking is not necessary to create saturation and to possibly dehydrate the air, if the particles have sufficient time to sediment. It is sufficient for the air to cool enough for cirrus to form during some part of the passing wave event. Boehm and Verlinde [2000] observed cirrus clouds just below the tropopause associated with Kelvin waves, supporting the importance of these waves as a dehydration mechanism.

\subsubsection{Regional absence of dehydration}

[33] The observations at Juazeiro do Norte in February and November 1997 as well as the observations at Christmas Island in March 1993 do not show any indication for dehydration in the upper troposphere. The upper troposphere is significantly warmer (Figure 6) and has more ozone (Figure 7) compared to both the western and eastern Pacific, but it does not have significantly larger amounts of water vapor and no saturation is observed at this longitude. 3.2.5. Comments on the different mechanisms

[34] The dehydration mechanisms that we present here are not unambiguous. Even though our observations show a clear separation between these cases, these mechanisms can operate at the same time and may produce a more complicated vertical structure in the profiles. While it appears that there is a clear difference between the presence and absence of saturation, temporal and spatial variabilities can wash out this difference.

[35] Dehydration at the temperature minimum happens in some, but not in all equatorial regions. In the regions, where dehydration is not observed, the water vapor concentration is controlled by long-range transport, i.e., by the complicated history of the air mass, which may have undergone convective and non-convective dehydration as well as mixing with stratospheric and possibly midlatitude air. Some aspects of this long-range transport have been discussed by Holton and Gettleman [2001].

\subsection{Seasonal Cycle of Dehydration}

[36] The observations at San Cristóbal cover two different seasons: late northern winter and late northern summer. In September the upper troposphere at San Cristóbal has slightly higher ozone and higher water vapor concentrations, but the warm temperatures prevent saturation (Figure 2b). Therefore there is a clear seasonal modulation of saturation occurrence in the eastern Pacific. If particles form as discussed in section 3.1 and sediment out, this would imply a similar seasonal preference in dehydration in the eastern Pacific.

[37] All March observations show a local water vapor maximum of $\sim 4$ ppmv between 20 and $21 \mathrm{~km}$, which is a snapshot of the "tape-recorder," in which the water vapor maximum, created in the previous northern summer months, has ascended to this level. In September, water vapor amounts decrease with altitude up to 22 to $23 \mathrm{~km}$, representing another tape-recorder snapshot, in which the minimum created in the previous northern winter months has been lifted to the observed altitude. September is at the end of the warm tropopause period (Figure 6) and air crossing the tropopause will create the local water vapor maximum between 20 and $21 \mathrm{~km}$ in March. Since air at the temperature minimum in September has around $6 \mathrm{ppmv}$ of water vapor, but the local maximum in March only around 4 ppmv, air entering the stratosphere in September has to be processed further even though it had passed the temperature minimum. This processing can be mixing with air from other longitudes, which may have lower water vapor concentrations, or further freeze-drying in the later parts of the year. Profiles at Juazeiro do Norte and at Trinidad $\left(10.7^{\circ} \mathrm{N}\right.$, $61.6^{\circ} \mathrm{W}$ [Mastenbrook, 1966]) show that in November, a new minimum is already established near $16.5 \mathrm{~km}$ and a local maximum remains near $18.5 \mathrm{~km}$, with water vapor 


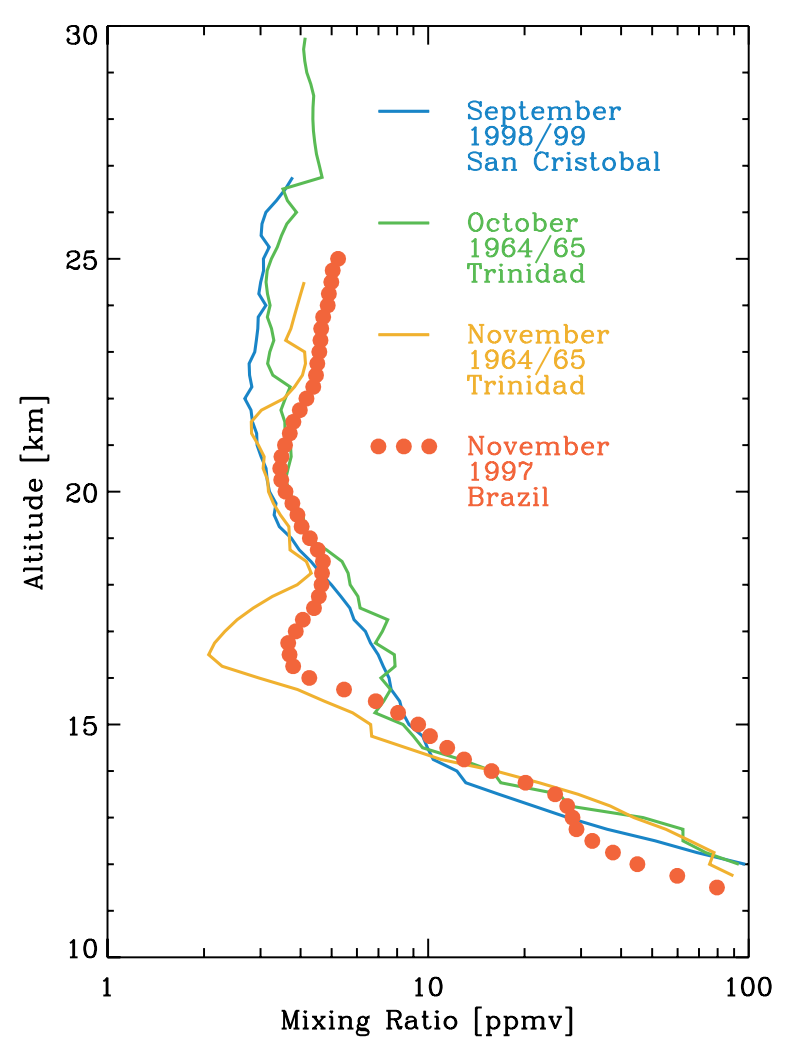

Figure 11. Development of the dehydration between September and November. The profiles at San Cristóbal and Trinidad are the average for all profiles of the month; the profile at Juazeiro is a single profile.

concentrations between 4 and 4.5 ppmv (Figure 11). The formation of the local water vapor minimum in the tropopause region is relatively rapid, since none of the September profiles at San Cristóbal and none of the October profiles at
Trinidad give any indication for the formation of this water vapor minimum. This may indicate that air, which had passed the temperature minimum at $16 \mathrm{~km}$ in September, is processed again or continuously at altitudes up to $18 \mathrm{~km}$. This implies that the saturation level rises faster than the air at the temperature minimum itself, which would allow for a second or ongoing dehydration of the same air until the coldest tropopause temperatures are reached [Reid and Gage, 1996]. It is also possible that long-range transport contributes to the formation of the new minimum, implying the reduction of the maximum at $18.5 \mathrm{~km}$ is caused by mixing of the moist air observed at Juazeiro do Norte and Trinidad in September with very dry air from other regions.

\subsection{Transition Region Around the Equatorial Tropopause}

[38] The ozone profiles at San Cristóbal show a similar structure to the ozone profiles at American Samoa analyzed by Folkins et al. [1999]. The mean ozone and lapse rate profiles for all March soundings at San Cristóbal are shown in Figure 12a. Ozone and lapse rate are uncorrelated in most individual soundings below $14 \mathrm{~km}(353 \mathrm{~K})$ but show a significant correlation above, indicating a similar mixing barrier over San Cristóbal as over American Samoa. In contrast, the ozone measurements in the western Pacific in March 1993 (Figure 12b) show extremely low ozone concentrations and a nearly adiabatic lapse rate close to the tropopause. Twelve out of 16 soundings show less than 10 ppbv of ozone above $15 \mathrm{~km}(357 \mathrm{~K})$ and 8 out of 16 soundings show less than 10 ppbv above $16 \mathrm{~km}$ (361 K). In these soundings, ozone and lapse rate do not show any correlation up to $16 \mathrm{~km}$. Therefore the observations of a mixing barrier at San Cristóbal and at Samoa are not representative for the entire equatorial region.

[39] The tropopause transition region, indicated by the mixing barrier around $14 \mathrm{~km}$, can also be identified by a layer of increasing RHI in the upper troposphere. At San
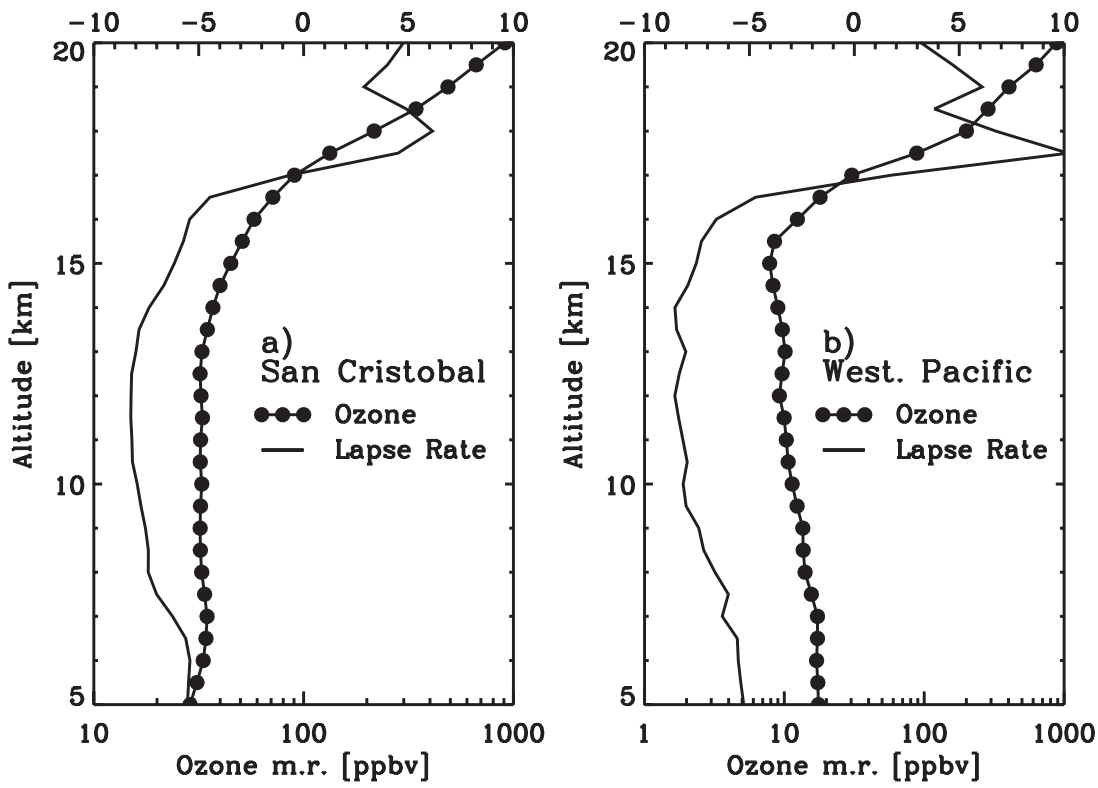

Figure 12. Ozone and lapse rate profile average (a) San Cristóbal, March 1998-2001 and (b) Western Pacific, March 1993. 

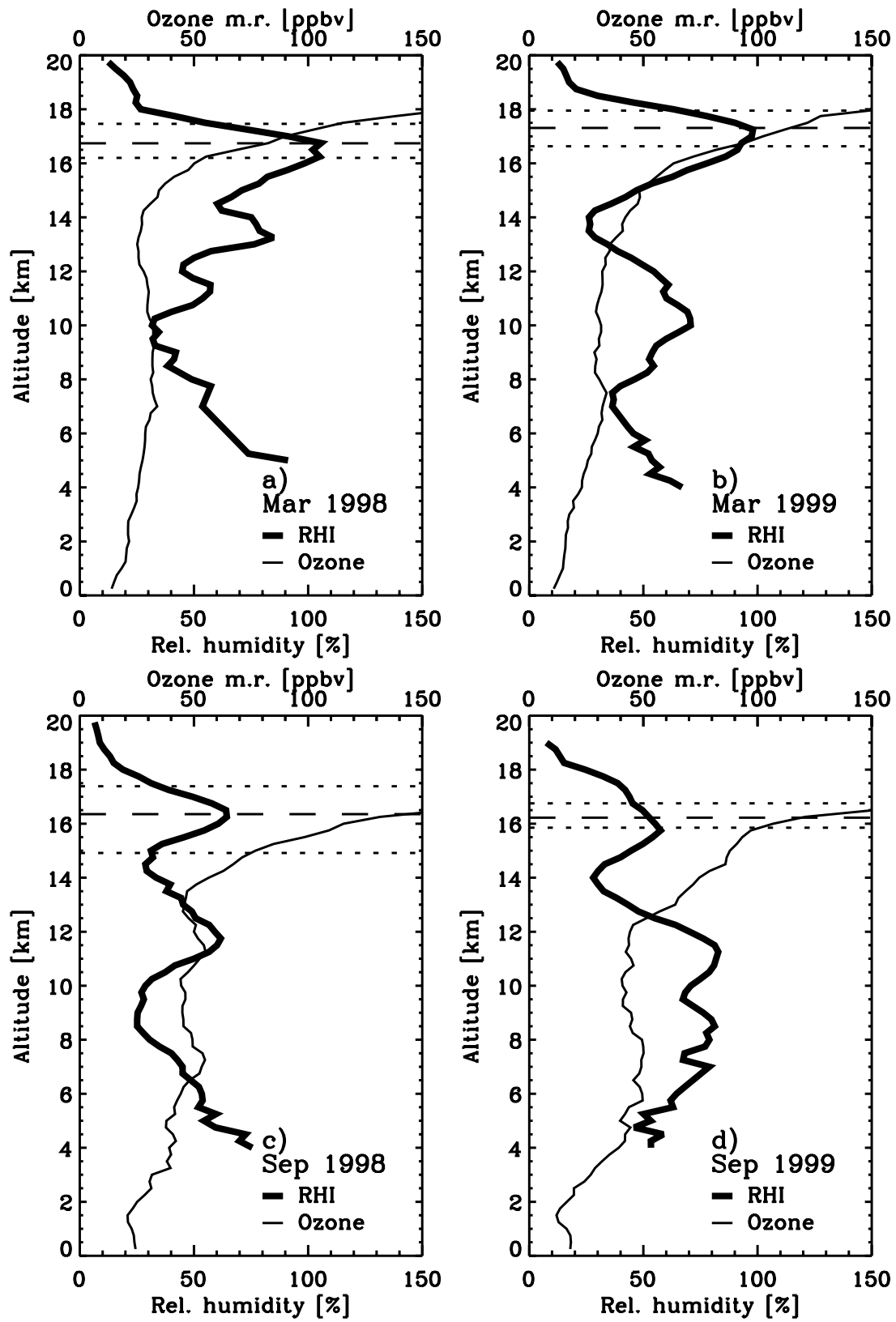

Figure 13. Average relative humidity with respect to ice and average ozone mixing ratio at San Cristóbal: (a) March 1998, (b) March 1999, (c) September 1998, and (d) September 1999. The dashed line indicates the mean tropopause, and the dotted lines indicate the highest and lowest altitude of the tropopause.

Cristóbal in March average RHI peaks at the tropopause (Figure 13) with values around $100 \%$. Below the tropopause, all profiles show a clear minimum in RHI that marks the transition between the drier middle troposphere and the moist tropopause region. In March 1999 (Figure 13b) the average RHI minimum is typically around $13.5 \mathrm{~km}$, and in each profile the minimum in RHI correlates with the increase in ozone. Therefore the minimum in RHI can be used as indicator for the lower end of the tropopause transition region.

[40] In March 1998 (Figure 13a), the minimum in RHI is in the middle troposphere around $10 \mathrm{~km}$, but the increase in ozone is above $15 \mathrm{~km}$. Deep convective activity during the El Niño 1997/1998 created the high relative humidity in the region between 10 and $15 \mathrm{~km}$ and a small minimum in RHI at $15 \mathrm{~km}$ is indicative of the higher boundary of the transition region. However, the three profiles that make up this average show a large variability, which makes this identification uncertain.

[41] In regions of suppressed convection, low ozone in the upper troposphere is indicative of air which has been lifted to the upper troposphere by deep convection [Kley et al., 1997]. While in these cases the middle troposphere experienced a considerable subsidence, rapidly lowering RHI [Salathe and Hartmann, 1997], the upper troposphere did not experience subsidence and remained at high values of RHI (Figure 14a). Here, the tropopause transition region can be identified by the region of high RHI, even 

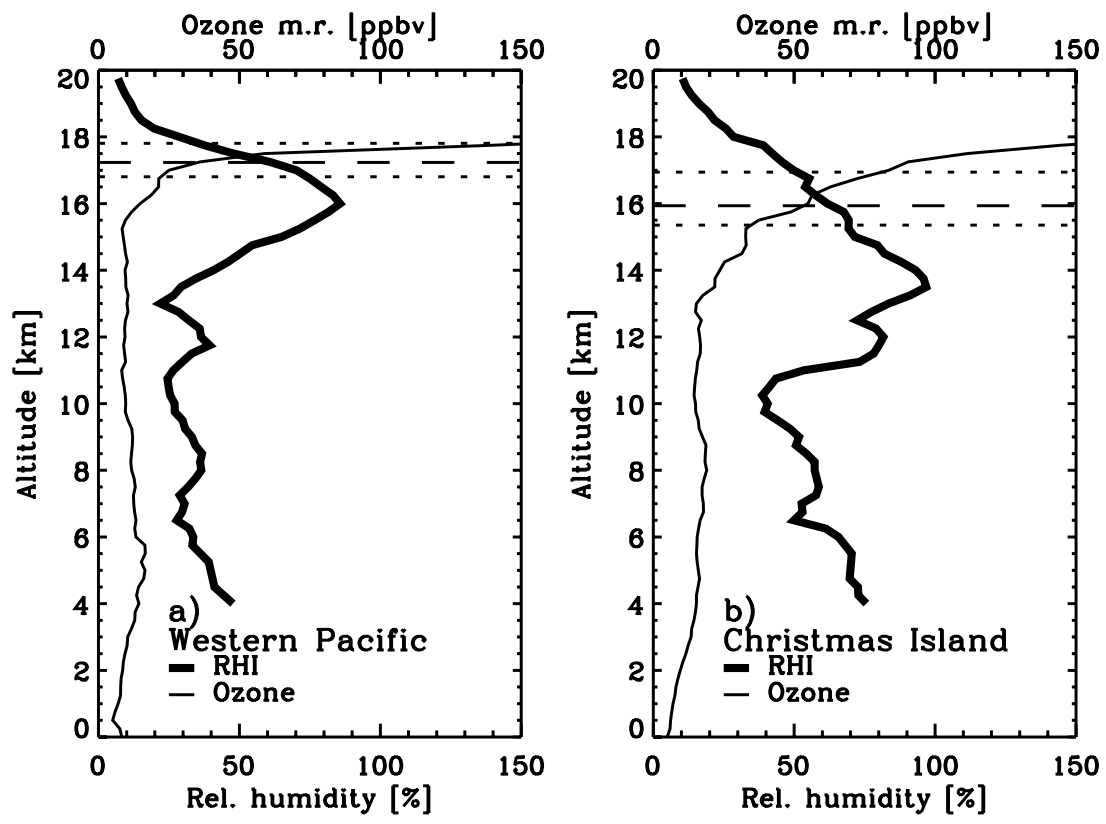

Figure 14. Same as Figure 13 for March 1993: (a) western Pacific profiles outside the deep convective region and (b) Christmas Island.

though the ozone concentrations are low. Mastenbrook [1965] reported identical observations in soundings of water vapor and ozone in November 1963 at Kwajalein Island $\left(8.72^{\circ} \mathrm{N}, 167.73^{\circ} \mathrm{E}\right)$, showing high values of $\mathrm{RHI}$ and very low ozone amounts in then upper troposphere above a dry middle troposphere. Thus the soundings in the western Pacific in March 1993 are likely to be representative for a large area of the western equatorial Pacific.

[42] The profiles at Christmas Island show on average a slightly modified structure (Figure 14b). Some observations were again taken close to deep convection, but this convection reached only to $\sim 14 \mathrm{~km}$, roughly 2 to $3 \mathrm{~km}$ lower than in the western Pacific. Ozone in the upper most troposphere was significantly higher than in the western and central Pacific, but RHI in this region was similar to the values of the central Pacific. Since close proximity of convective activity moistens the middle troposphere, the transition region is detectable only in the profiles of ozone, similar to the March 1998 profiles at San Cristóbal.

[43] Regions with high ozone concentrations in the troposphere, such as South America, especially during the biomass-burning season, may not show the transition region in ozone since the stratospheric ozone influx may be of similar magnitude compared to typical tropospheric ozone. In these cases the transition region may only be identifiable by the increase in RHI below the tropopause. The sounding at Juazeiro do Norte in February 1997 (Figure 15a) shows a generally moist troposphere, but it also shows a very distinct minimum in RHI at $14 \mathrm{~km}$, correlating with a marked increase in ozone at the same altitude. February 1997 was generally characterized by frequent convective activity in the region, reaching up to about $13 \mathrm{~km}$. Above this altitude, the transition layer becomes obvious in both ozone and RHI. The profile at Juazeiro do Norte in November 1997 (Figure 15b) shows a more complicated structure in ozone, with very high ozone concentrations in the middle troposphere likely produced by biomass burning. The RHI profile shows a more complicated structure as well, but both the RHI maximum at the tropopause and the RHI minimum at $12 \mathrm{~km}$ are clearly pronounced. The RHI minimum at $12 \mathrm{~km}$ again indicates the base of the transition layer.

\subsection{Formation of the Transition Region}

[44] The extremely steep gradient of ozone over convective regions in the western Pacific demonstrates that the tropopause is basically impermeable to downward transport for ozone. The extreme vertical gradient of water vapor at the same level indicates that in this case the tropopause is also impermeable to upward transport directly above deep convective regions. Deep convection, thus, creates the typical signature of low ozone and high RHI indicative for mostly tropospheric air, which can persist for considerable distances from the source. Under these conditions, a transition layer in the upper troposphere is identifiable only by the high values of RHI above a dry middle troposphere, but not by a noticable change in the ozone concentration.

[45] A significant transition was observed in a sequence of soundings at Christmas Island showing a strong build up of ozone below the tropopause over 5 days, with higher ozone remaining below the tropopause after the passing of this event (Figure 16). These data indicate a wave-breaking event, which transports low water vapor and high ozone concentrations to below the tropopause. After this event has passed, the general upward motion in this region, driven by the extratropical stratospheric pump, raises RHI, while maintaining the mixing ratio of water vapor up to the point where saturation is reached. This process maintains high values of RHI and contributes strongly to the source of ozone below the tropopause. Thus the water vapor content of the transition region is controlled both by the initial setup through deep convection and the drying through the slow ascent. 

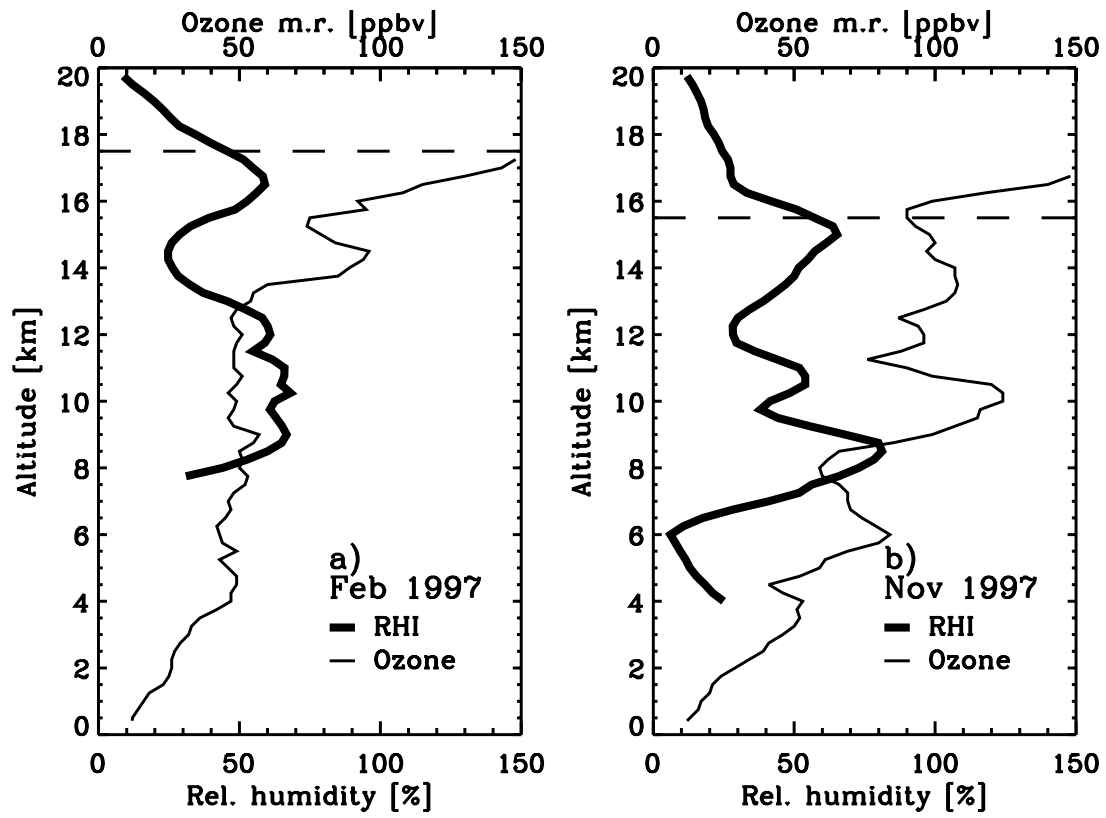

Figure 15. Relative humidity with respect to ice and ozone mixing ratio at Juazeiro do Norte: (a) 14 February 1997 and (b) 11 November 1997. The dashed line indicates the tropopause.

[46] The transition region at San Cristóbal in September (Figures $13 \mathrm{c}$ and 13d) exhibits lower RHI values compared to March, possibly due to the slower ascending motion during the northern summer and fall, which no longer balances the downward mixing of low water vapor concentrations to maintain high values of RHI. Furthermore, the seasonal cycle of temperature correlates with the seasonal cycle of the extratropical stratospheric pump to several $\mathrm{km}$ below the tropopause [Reid and Gage, 1996], supporting the idea that the vertical extent of the transition layer has a strong seasonal cycle as well.

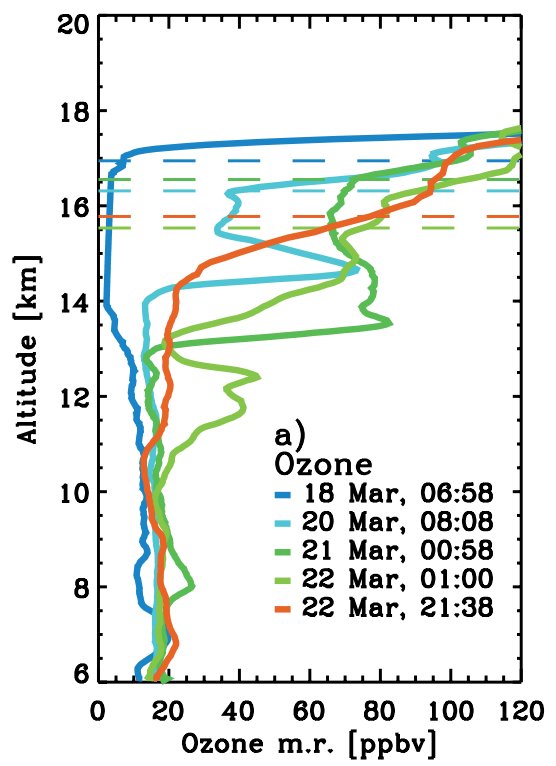

[47] It is important to point out that the lower boundary of this transition layer is anything but a well-defined barrier. While many observations clearly show the existence of this barrier, it is most likely subject to frequent penetrations by convection, which can inject air into the lower parts of the transition region, but which cannot detrain air at the tropopause. The relative importance of the processes at this level strongly depends on season as well as geographic region. Any study investigating just one region or just one season is unlikely to capture a representative view of the processes at the bottom of the transition region.

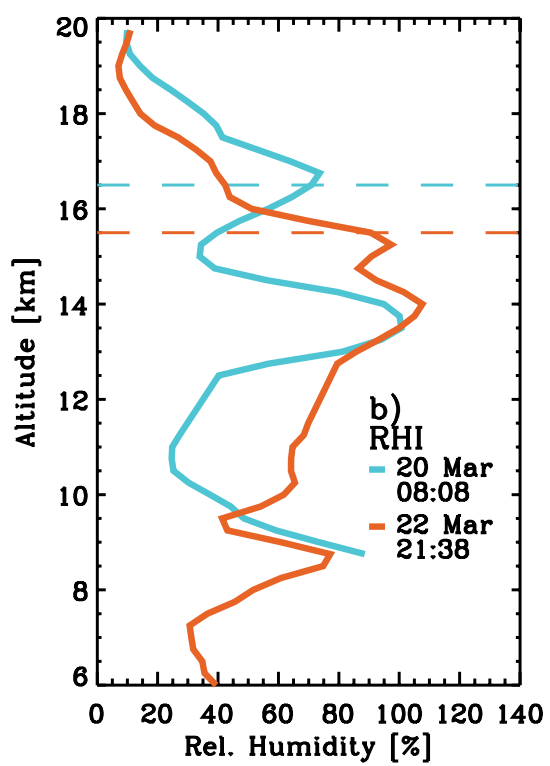

Figure 16. Development of high ozone and low relative humidity below the tropopause at Christmas Island. The last profile of this series (22 March 1993, 2138 UT) shows the lower humidity and higher ozone concentration below the tropopause after the event has passed. 


\subsection{Source of Ozone in the Transition Layer}

[48] The work by Fujiwara et al. [1998], as well as some data presented here, indicate that a significant source of ozone in the upper tropical troposphere is the transport due to large-scale wave breaking at the equatorial tropopause. However, it is not clear, whether this is the dominating process. Isentropic transport from the midlatitude lower stratosphere into the tropical upper troposphere may as well contribute to the increase of ozone in this region. Recirculation of "aged" stratospheric air [Tuck et al., 1997] into the tropical lower stratosphere and upper troposphere indicates a significant contribution of midlatitude air. This could take place in Rossby wave breaking events [Postel and Hitchman, 1999], which may also be linked to regions of anomalous westerly winds in the equatorial tropics [Waugh and Polvani, 2000]. The ozone data give some indication that anomalous westerly winds may be associated with some events of higher ozone, however, the seasonal distributions of these Rossby wave breaking events found by Postel and Hitchman [1999] or Waugh and Polvani [2000] cannot explain the seasonal cycle of upper tropospheric ozone in the equatorial latitudes. Figure 7 does not indicate a seasonal cycle of ozone directly at the tropopause over San Cristóbal. However, on potential temperature surfaces, there is a weak cycle with a maximum during September/ October and a minimum during the northern winter months, which is characteristic of several other tropical stations [Oltmans et al., 2001]. Thus it seems unlikely that deep intrusions of midlatitude air are the main source for ozone in the tropical upper troposphere.

[49] The contributions of breaking mesoscale gravity waves generated by tropical cyclones [Pfister et al., 1993] and in situ production of ozone are other contributing factors for ozone in the tropical tropopause transition layer.

\subsection{Implications for Tropical Tropopause Cirrus Clouds}

[50] The observations showed frequent saturation and supersaturation at the temperature minimum during March, both in the western and eastern Pacific, allowing for formation of water ice clouds. In the western Pacific, these clouds were characterized by low ozone concentrations, likely with deep convective outflow. In the eastern Pacific, where much higher ozone concentrations were observed, these clouds were more likely produced in situ through slow ascent and possibly homogeneous nucleation. These observations are in agreement with the climatology of cirrus clouds by Wang et al. [1996] and emphasize that cirrus clouds at the tropical tropopause are not necessarily connected to deep convection. The observations in September 1998, which show the decrease of RHI in the downward phase of a Kelvin wave and the increase of RHI in the upward phase, support the observations by Boehm and Verlinde [2000], who observed cirrus clouds assuming in conjunction with the passage of Kelvin waves.

[51] In the eastern Pacific in September, at Christmas Island in March, and at Juazeiro do Norte in November and February there is no saturation in the tropopause transition region, despite a very pronounced increase in RHI below the tropopause. None of the soundings would support the presence of water ice cirrus clouds at the tropopause. However, the observations by Winker and Trepte [1998], which were obtained in September 1994, show widespread subvisible cirrus at the tropical tropopause, which may be an indication, that some of these clouds are in fact not composed of water, but rather of a mixture of water and nitric acid, similar to clouds, forming in the winter polar stratospheres above the frost-point temperature. Hamill and Fiocco [1988] pointed to the possibility of nitric acid trihydrate particles at this altitude. Some evidence for $\mathrm{HNO}_{3}$-containing particles at the tropical tropopause was found by Murphy et al. [1993], adding additional support to the hypothesis that not all tropopause cirrus are pure water ice clouds.

\section{Summary and Conclusion}

[52] Balloon-borne observations of frost-point temperature and ozone at several equatorial locations provide an accurate data set of water vapor and ozone with high vertical resolution around the tropical tropopause. The sites studied here are San Cristóbal, Galápagos, Ecuador in the eastern Pacific, Juazeiro do Norte in northeastern Brazil, a ship cruise in the western equatorial Pacific, and Christmas Island in the central equatorial Pacific. At San Cristóbal the data cover March and September of 1998 and 1999. The characteristic processes and regions described above are summarized in Table 1 and are shown as a schematic in Figure 17. Deep convection in the western Pacific transports lower tropospheric air to the tropopause, dehydrating the air to very low mixing ratios, while maintaining high relative humidities and low ozone concentrations. Downward motion in the lower stratosphere above regions of deep convection (western Pacific) may be responsible for the extremely steep gradients of water vapor and ozone observed directly at the tropopause. Away from regions of deep convection, subsidence lowers the relative humidity in the middle troposphere, however, the upper troposphere remains at high relative humidities and low ozone values indicative of recent convective origin of the air. In regions, where deep convection does not reach the tropical tropopause or where subsidence prevails, saturation and subsequent dehydration within the transition layer may still occur, driven only by slow large-scale ascent. Kelvin waves and other large-scale waves may contribute to the dehydration process in these regions. Not all equatorial regions show saturation and some regions may not participate at all in the dehydration of rising air. There is a strong seasonal cycle in the dehydration process at the tropical tropopause. At San Cristóbal, nonconvective dehydration was observed only during the March campaigns, but not during the September campaigns.

[53] A transition region around the tropopause can be identified by the increase in relative humidity with altitude up to the tropopause. Wave breaking across the tropical tropopause and midlatitude intrusions are a source for ozone in this transition region. The general upward motion in the transition region driven by the stratospheric extratropical pump maintains a high relative humidity within this layer. The seasonal cycle of relative humidity within the transition region is driven by the seasonal cycle of the stratospheric extratropical pump and for a given site the relative importance for the dehydration process changes with season. On the basis of our measurements from several equatorial sites, it appears likely that the zonal average of the tropopause relative humidity shows a seasonal cycle as well. Furthermore, 
Table 1. Features of the Different Dehydration Regimes

\begin{tabular}{|c|c|c|c|}
\hline Region & Time Period & Sounding Feature & Conclusion \\
\hline Western tropical Pacific & March & $\begin{array}{l}\text { saturation over a deep layer } \\
\text { with low ozone concentrations }\end{array}$ & $\begin{array}{l}\text { deep convective injection } \\
\text { of air with simultaneous } \\
\text { dehydration }\end{array}$ \\
\hline Eastern tropical Pacific & March & $\begin{array}{l}\text { saturation over a deep layer } \\
\text { with high ozone concentrations }\end{array}$ & $\begin{array}{l}\text { dehydration of air through } \\
\text { slow ascent, which has not } \\
\text { recently ascended from the } \\
\text { surface }\end{array}$ \\
\hline Eastern tropical Pacific & September & $\begin{array}{l}\text { absence of saturation } \\
\text { in the upper troposphere }\end{array}$ & $\begin{array}{l}\text { absence of dehydration } \\
\text { during the times of the } \\
\text { warmest tropopause }\end{array}$ \\
\hline Eastern tropical Pacific & September & $\begin{array}{l}\text { near saturation in the upward } \\
\text { arm of a passing Kelvin wave }\end{array}$ & dehydration in Kelvin waves \\
\hline Northeastern Brazil & November, February & absence of saturation & $\begin{array}{l}\text { absence of dehydration } \\
\text { during the times of the } \\
\text { coldest tropopause }\end{array}$ \\
\hline All regions & all periods & $\begin{array}{l}\text { local maximum of relative } \\
\text { humidity in the tropopause } \\
\text { region, and local minimum of } \\
\text { relative humidity below }\end{array}$ & $\begin{array}{l}\text { tropical tropopause } \\
\text { transition region is } \\
\text { indicated by layer of higher } \\
\text { relative humidity }\end{array}$ \\
\hline
\end{tabular}

the seasonal cycle of the tropopause temperature shows a rapid cooling between September and November, which allows for a secondary dehydration of air in November, which had already crossed the tropopause in September. Since average vertical velocities in the lower stratosphere are significantly larger during the northern winter, it appears that the northern winter months play a much stronger role in the dehydration of air entering the stratosphere than the northern summer months.
[54] Considering that the tropopause temperature in the equatorial eastern Pacific during September is too warm to allow saturation and the presence of cirrus clouds, reports of subvisible cirrus in this region may indicate that these clouds are not ice clouds but rather a mixture of nitric acid and water similar to the different types of stratospheric clouds found in the winter polar stratosphere.

[55] Our data identify three different dehydration processes that can occur at the tropical tropopause. They also

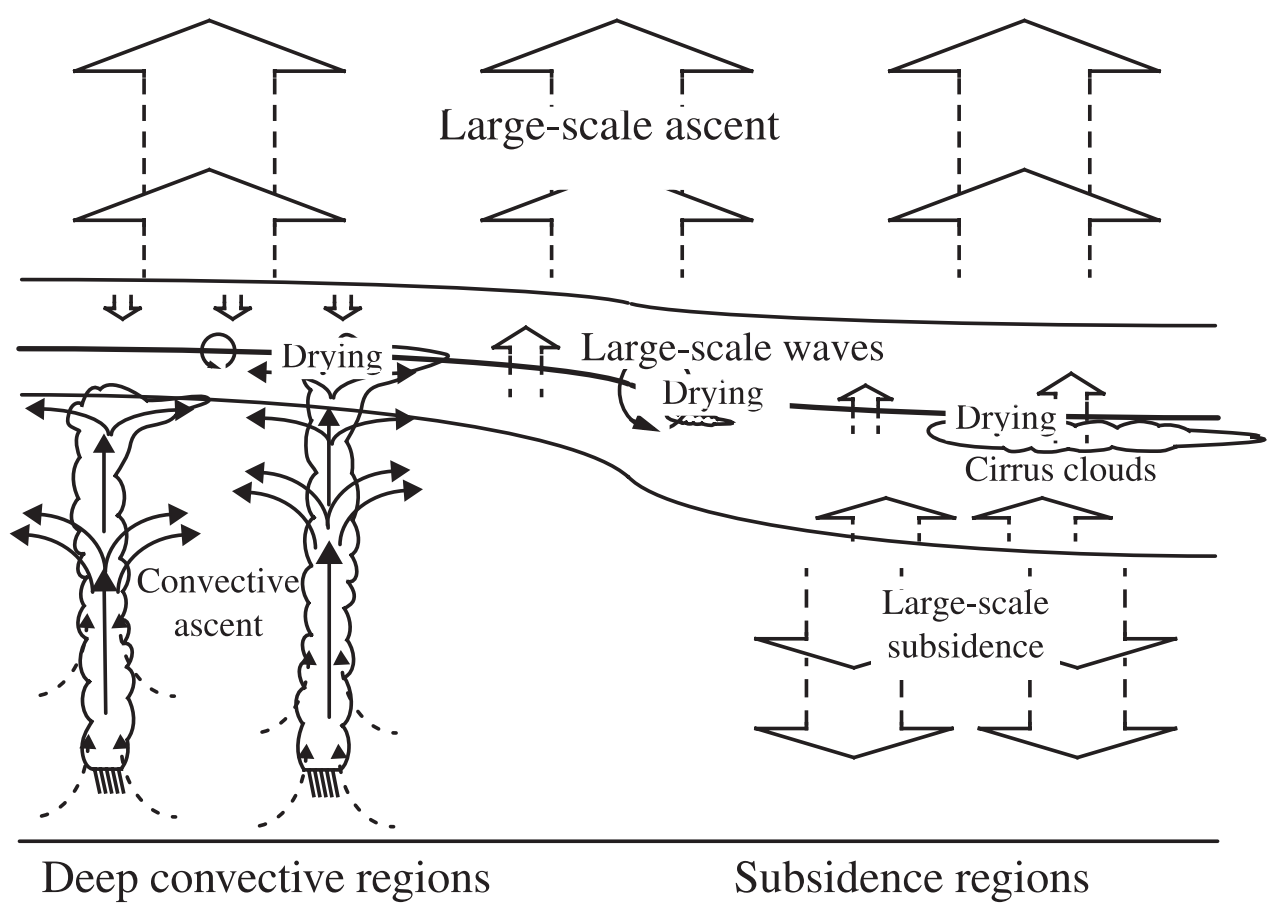

Figure 17. Schematic of the transport and dehydration processes across the tropical tropopause. The tropopause is indicated by a solid line, the tropopause transition region is indicated by thin lines above and below. Drying occurs at the temperature minimum close to the lapse rate tropopause induced by convection, large-scale waves and slow ascent. Breaking of large-scale waves is one of the sources of ozone in the tropopause transition region below the tropopause. Convective regions have a different impact on the transition region, depending on the altitude that the convection reaches. 
show that not all regions participate in dehydration of air in the tropopause transition region. Air entering the stratosphere will likely have experienced a mixed history of the various dehydration and mixing processes, making quantitative modeling very difficult. There is a regional preference as well as a seasonal preference for dehydration and that the transport of water vapor into the stratosphere does not occur in a temporally and spatially uniform manner, contrary to Dessler [1998], who suggested that theories including spatial and temporal preference "are no longer necessary." Newell and Gould-Stewart [1981] suggested that air enters the stratosphere predominantly over the western Pacific during the northern hemisphere winter and early spring, as well as over the Indian Ocean during the monsoon season. Their study was based mostly on radiosonde observations available at that time, with very limited equatorial water vapor observations. Our study neither refutes nor proves their hypothesis, but rather makes additional necessary refinements. The regional and seasonal preference for the dehydration process does not necessarily imply that air enters the stratosphere at these longitudes. Deep convective regions play an important role as source of air in the transition region below the tropopause. This air may be transported horizontally away from the area of deep convection before entering the stratosphere. Furthermore, overshooting deep convection may directly inject air into the lowermost stratosphere. If the tropopause temperature is cold enough, air in the transition region may be dehydrated further in nonconvective regions. The extratropical stratospheric pump provides a zonally averaged view, but there is no reason to assume that the vertical ascent in the lower tropical stratosphere is zonally symmetric. Our study has not addressed this issue, but studies indicating descending motion above the deep convective regions in the maritime continent already indicate that there are important zonal asymmetries in the vertical ascent in the lower tropical stratosphere. It is not implausible, that cold tropopause temperatures also correlate with regions of stronger vertical ascent, which would not only imply a regional preference for the dehydration of air entering the stratosphere, but also a regional preference for the entry point. It is also important to point out, that there has been a significant increase in stratospheric water vapor and at the same time a decrease in the tropical tropopause temperature. These two trends are not easily reconcilable. They also show that the atmosphere that led to the formulation of the stratospheric fountain hypothesis has changed and that the conclusions that are derived now will necessarily be different without refuting the stratospheric fountain hypothesis.

[56] As a last point we want to question the classifications "stratospheric" and "tropospheric" for air, which is respectively above and below the lapse rate tropopause. Air in the transition region has stratospheric signatures, like higher ozone concentrations and higher vertical stability than air in the middle troposphere. At the same time, this air has higher values of relative humidity and typical tropospheric tracers as well as the potential for cloud formation. Air in this region is a mixture of both stratospheric and tropospheric and the question, whether convection overshoots the tropopause or not should be replaced by the question, of how deep convection penetrates into the transition layer and how much do nonconvective and wave-driven processes contribute to the makeup of the air in this region.

[57] Acknowledgments. The authors like would like to thank the United Nations Development Program and Sra. Sandra Darquea for their support in Quito, Ecuador; the National Scientific Ballooning Facility for their support in Juazeiro do Norte; Zim Sherman for the preparation of the instrument; as well as Ian Folkins and two anonymous reviewers for their helpful comments. The observations were financially supported in part by the Sumitomo Foundation, Monbusho International Scientific Research Program, and Asahi Breweries Foundation.

\section{References}

Atticks, M. G., and G. D. Robinson, Some features of the structure of the tropical tropopause, Q. J. R. Meteorol. Soc., 109, 295-308, 1983.

Boehm, M. T., and J. Verlinde, Stratospheric influence on upper tropospheric tropical cirrus, Geophys. Res. Lett., 27, 3209-3212, 2000.

Brewer, A. W., Evidence for a world circulation provided by measurements of helium and water vapor distribution in the stratosphere, Q. J. R. Meteorol. Soc., 75, 351-363, 1949.

Danielsen, E. F., A dehydration mechanism for the stratosphere, Geophys. Res. Lett., 9, 605-608, 1982.

Danielsen, E. F., In situ evidence of rapid, vertical, irreversible transport of lower tropospheric air into the lower tropical stratosphere by convective cloud turrets and by larger-scale upwelling in tropical cyclones, J. Geophys. Res., 98, 8665-8681, 1993.

Dessler, A. E., A reexamination of the "stratospheric fountain" hypothesis, Geophys. Res. Lett., 25, 4165-4168, 1998.

Dlugokencky, E. J., K. A. Masarie, P. M. Lang, and P. P. Tans, Continuing decline in the growth rate of the atmospheric methane burden, Nature, 393, 447-450, 1998.

Folkins, I., M. Loewenstein, J. Podolske, S. J. Oltmans, and M. Proffitt, A barrier to vertical mixing at $14 \mathrm{~km}$ in the tropics: Evidence from ozonesondes and aircraft measurements, J. Geophys. Res., 104, 22,09522,102, 1999.

Forster, P.-M. de F., and K. P. Shine, Stratospheric water vapour changes as a possible contributor to observed stratospheric cooling, Geophys. Res. Lett, 26, 3009-3312, 1999.

Fujiwara, M., K. Kita, and T. Ogawa, Stratosphere-troposphere exchange of ozone associated with the equatorial Kelvin wave as observed with ozonesondes and rawinsondes, J. Geophys. Res, 103, 19,173-19,182, 1998.

Fujiwara, M., F. Hasebe, M. Shiotani, N. Nishi, H. Vömel, and S. Oltmans, Water vapor control at the tropopause by the equatorial Kelvin wave observed over Galapagos, Geophys. Res. Lett., 28, 3143-3146, 2001.

Gage, K. S., J. R. McAfee, D. A. Carter, A. C. Riddle, G. C. Reid, and B. B. Balsley, Direct measurement of long-term mean vertical motions over the tropical Pacific using wind-profiling Doppler radar, Science, 254, 1771 1773, 1991.

Hamill, P., and G. Fiocco, Nitric-acid aerosols at the tropical tropopause, Geophys. Res. Lett., 15, 1189-1192, 1988.

Hartmann, D. L., J. R. Holton, and Q. Fu, The heat balance of the tropical tropopause, cirrus, and stratospheric dehydration, Geophys. Res. Lett., 28 , 1969-1972, 2001.

Hasebe, F., H. Vömel, M. Shiotani, N. Nishi, S. Oltmans, T. Ogawa, and K. Gage, First results from SOWER/Pacific, SPARC Newsl., 12, 22-23, 1999.

Highwood, E. J., and B. J. Hoskins, The tropical tropopause, Q. J.R. Meteorol. Soc., 124, 1579-1604, 1998.

Holton, J. R., and A. Gettelman, Horizontal transport and the dehydration of the stratosphere, Geophys. Res. Lett., 28, 2799-2802, 2001.

Holton, J. R., P. H. Haynes, M. E. McIntyre, A. R. Douglass, R. B. Brood, and L. Pfister, Stratosphere-troposphere exchange, Rev. Geophys, 33, 403-439, 1995.

Kley, D., E. J. Stone, J. W. Drummond, W. J. Harrop, A. L. Schmeltekopf, and T. L. Thompson, In situ measurements of the mixing ratio of water vapor in the stratosphere, J. Atmos. Sci., 36, 2514-2524, 1979.

Kley, D., A. L. Schmeltekopf, K. K. Kelly, R. H. Winkler, T. L. Thompson, and M. McFarland, Transport of water vapor through the tropical tropopause, Geophys. Res. Lett., 9, 617-620, 1982.

Kley, D., H. G. J. Smit, H. Vömel, S. J. Oltmans, H. Grassl, V. Ramanathan, and P. J. Crutzen, Extremely low upper tropospheric ozone observations in the convective regions of the Pacific, Science, 274, 230-233, 1996.

Kley, D., H. G. J. Smit, H. Vömel, H. Grassl, V. Ramanathan, P. J. Crutzen, S. Williams, J. Meywerk, and S. J. Oltmans, Tropospheric water vapor and ozone cross sections in a zonal plane over the equatorial Pacific, $Q . J$. R. Meteorol. Soc., 123, 2009-2040, 1997. 
Komhyr, W. D., R. A. Barnes, G. B. Brothers, J. A. Lathrop, and D. P. Opperman, Electro-chemical concentration cell ozonesonde performance evaluation during STOIC 1989, J. Geophys. Res., 100, 9231-9244, 1995.

Mastenbrook, H. J., The Vertical Distribution of Water Vapor Over Kwajalein Atoll, Marshall Islands, Tech. Rep. NRL 6367, Naval Res. Lab., Washington, D. C., 1965.

Mastenbrook, H. J., Water Vapor Observations at Low, Middle and High Latitudes During 1964 and 1965, Tech. Rep. NRL 6447, 202 pp., Naval Res. Lab., Washington, D. C., 1966.

Mastenbrook, H. J., Water vapor distribution in the stratosphere and the high troposphere, J. Atmos. Sci., 25, 299-311, 1968.

Mastenbrook, H. J., and J. E. Dinger, The Measurement of Water Vapor Distribution in the Stratosphere, Tech. Rep. NRL 5551, Naval Res. Lab., Washington, D. C., 1961.

Miloshevich, L. M., H. Vömel, A. Paukkunen, A. J. Heymsfield, and S. J. Oltmans, Characterization and correction of relative humidty measurements from Vaisala RS80-A radiosondes at cold temperatures, J. Atmos Oceanic Technol., 18, 135-156, 2001.

Mote, P. W., et al., An atmospheric tape recorder: The imprint of tropical tropopause temperatures on stratospheric water vapor, J. Geophys. Res., 101, 3989-4006, 1996.

Murphy, D. M., D. W. Fahey, M. H. Proffitt, S. C. Liu, K. R. Chan, C. S. Eubank, S. R. Kawa, and K. K. Kelly, Reactive nitrogen and its correlation with ozone in the lower stratosphere and upper troposphere, J. Geophys. Res., 98, 8751-8773, 1993.

Newell, R. E., and S. Gould-Stewart, A stratospheric fountain?, J. Atmos. Sci., 38, 2789-2796, 1981.

Nishida, M., A. Shimizu, T. Tsuda, C. Rocken, and R. H. Ware, Seasonal and longitudinal variations in the tropical tropopause observed with the GPS occultation technique (GPS/MET), J. Meteorol. Soc. Jpn., 78, 691 $700,2000$.

Oltmans, S. J., H. Vömel, D. J. Hofmann, K. H. Rosenlof, and D. Kley, The increase in stratospheric water vapor from balloonborne frost-point hygrometer measurements at Washington, D. C., and Boulder, Colorado, Geophys. Res. Lett., 21, 3453-3456, 2000.

Oltmans, S. J., et al., Ozone in the Pacific tropical troposphere from ozonesonde observations, J. Geophys. Res., 106, 32,503-32,526, 2001

Pfister, L., K. R. Chan, T. P. Bui, S. Bowen, M. Legg, B. Gray, K. Kelly, M Proffitt, and W. Starr, Gravity waves generated by a tropical cyclone during the STEP tropical field program: A case study, J. Geophys Res., 98, 8611-8638, 1993.

Postel, G. A., and M. H. Hitchman, A climatology of Rossby wave breaking along the subtropical tropopause, J. Atmos. Sci., 56, 359-373, 1999

Reid, G. C., and K. S. Gage, The tropical tropopause over the western Pacific: Wave driving, convection, and the annual cycle, J. Geophys Res., 101, 21,233-21,241, 1996.

Russel, P. B., L. Pfister, and H. B. Selkirk, The tropical experiment of the stratosphere-troposphere exchange project (STEP): Science objectives, operations, and summary findings, J. Geophys. Res., 98, 8563-8589, 1993.

Salathe, E. P., Jr., and D. L. Hartmann, A trajectory analysis of tropical upper-tropospheric moisture and convection, J. Clim., 10, 2533-2547, 1997.

Selkirk, H. B., The tropopause cold trap in the Australian monsoon during STEP/AMEX 1987, J. Geophys. Res., 98, 8591-8610, 1993.

Sherwood, S. C., A "stratospheric drain" over the maritime continent, Geophys. Res. Lett., 27, 677-680, 2000.

Smith, C. A., J. D. Haigh, and R. Toumi, Radiative forcing due to trends in stratospheric water vapour, Geophys. Res. Lett, 28, 179-182, 2001.
Tabazadeh, A., E. J. Jensen, and O. B. Toon, A model description for cirrus cloud nucleation from homogeneous freezing of sulfate aerosols, J. Geophys. Res., 102, 23,845-23,850, 1997.

Teitelbaum, H., M. Moustaoui, C. Basdevant, and J. R. Holton, An alternative mechanism explaining the hygropause formation in tropical regions, Geophys. Res. Lett., 27, 221-224, 2000.

Thompson, A. M. et al., The 1998-2000 SHADOZ (Southern Hemispheric Additional Ozonesondes) tropical ozone climatology: Comparison with TOMS and groundbased measurements, J. Geophys., Res., 107, 10.1029/2001JD000967, in press, 2002.

Tuck, A. F., et al., The Brewer-Dobson circulation in the light of high altitude in situ aircraft observations, Q. J. R. Meteorol. Soc., 123, 169, 1997.

Vömel, H., S. J. Oltmans, D. J. Hofmann, T. Deshler, and J. M. Rosen, The evolution of the dehydration in the Antarctic stratospheric vortex, $J$. Geophys. Res., 100, 13,919-13,926, 1995a.

Vömel, H., S. J. Oltmans, D. Kley, and P. J. Crutzen, New evidence for the stratospheric dehydration mechanism in the equatorial Pacific, Geophys. Res. Lett., 22, 3235-3238, 1995b.

Vömel, H., M. Rummukainen, R. Kivi, J. Karhu, T. Turunen, E. Kyrö, J. M. Rosen, N. T. Kjome, and S. J. Oltmans, Dehydration and sedimentation of ice particles in the Arctic stratospheric vortex, Geophys. Res. Lett., 24, 795-798, 1997

Vömel, H., F. Hasebe, M. Shiotani, M. Niwano, S. Oltmans, N. Nishi, and T. Ogawa, Water vapor and ozone observations during SOWER/Pacific 1998 and 1999, paper presented at Quadrennial Ozone Symposium, Int. Ozone Comm./Int. Assoc. for Meteorol. and Atmos. Sci., Sapporo, Japan, July 2000.

Wang, P.-H., P. Minnis, M. P. McCormick, G. S. Kent, and K. M. Skeens, A 6-year climatology of cloud occurrence frequency from Stratospheric Aerosol and Gas Experiment II observations (1985-1990), J. Geophys. Res., 101, 2940-29,429, 1996.

Waugh, W. W., and L. M. Polvani, Climatology of intrusions into the tropical upper troposphere, Geophys. Res. Lett., 23, 3857-3860, 2000.

Winker, D. M., and C. R. Trepte, Laminar cirrus observed near the tropical tropopause by LITE, Geophys. Res. Lett., 25, 3351-3354, 1998.

World Meteorology Organization, Meteorology-A three-dimensional science: Second session of the commission for aerology, WMO Bull., IV(4), 134-138, 1957.

Yulaeva, E., J. R. Holton, and J. M. Wallace, On the cause of the annual cycle in tropical lower stratospheric temperatures, J. Atmos. Sci., 52, $169-174,1994$

Zhou, X.-L., M. A. Geller, and M. Zhang, Cooling trend of the tropical cold point tropopause temperatures and its implications, J. Geophys. Res., 106, $1511-1522,2001$

M. Agama, J. Cornejo, H. Enriquez, and F. Paredes, Instituto Nacionál de Meteorología y Hidrología, Iñaquito 700 y Correa, Quito, Ecuador.

F. Hasebe, Graduate School of Environmental Earth Science, Hokkaido University, Sapporo 060-0810, Japan.

S. J. Oltmans and B. J. Johnson, Climate Monitoring and Diagnostics Laboratory, National Oceanic and Atmospheric Administration, Boulder, CO 80305, USA.

M. Fujiwara, N. Nishi, and M. Shiotani, Radio Science Center for Space and Atmosphere, Kyoto University, Uji, Kyoto 611-0011, Japan.

H. Vömel, CIRES, University of Colorado, Boulder, CO 80309-0216, USA. (holger.voemel@noaa.gov) 